\title{
New data on Eulipotyphla (Insectivora, Mammalia) from the Late Miocene to the Middle Pleistocene of Ukraine
}

\author{
Barbara Rzebik-Kowalska and Leonid I. Rekovets
}

\begin{abstract}
Remains of Erinaceidae, Talpidae and Soricidae (Eulipotyphla, Mammalia) from eight localities are described: three (Popovo 3, MN11, Verkhnya Krynitsa 2, MN11/ MN12 and Lobkove, MN12) from the Late Miocene, two (Verkhnya Krynitsa 1, early MN16 and Popovo 2, late MN16) from the Pliocene, one (Popovo 1, MN16/MN17) from the Pliocene/Pleistocene boundary, one (Popovo 0, MN17) from the Early Pleistocene and one (Medzhybozh, Q3) from the early Middle Pleistocene. Short geological characteristics as well as local and stratigraphic positions were described. The list of insectivore species includes: Schizogalerix sp., cf. Mygalinia hungarica, Ruemkelia sp., Desmana sp., cf. Desmana sp., Miosorex grivensis, cf. Miosorex sp., Crusafontina cf. kormosi, cf. Asoriculus sp., Neomysorex alpinoides, Neomys newtoni, Petenyia dubia, Petenyia hungarica, cf. Beremendia minor, Beremendia fissidens, Zelceina sp. Both the abundance of insectivore remains and their taxonomic diversity vary among localities. The most numerous and diverse assemblage (10 taxa of three families) is that of the Late Miocene Verkhnya Krynitsa 2. The remaining seven localities yielded one to three species. The remains are described, measured and illustrated, and their systematic positions and distributions are discussed.
\end{abstract}

Barbara Rzebik-Kowalska. Institute of Systematics and Evolution of Animals, Polish Academy of Sciences, Sławkowska 17, 31-016 Kraków, Poland rzebik@isez.pan.krakow.pl

Leonid I. Rekovets. University of Environmental and Life Sciences of Wrocław, Chełmoński 38c, 51-630

Wrocław, Poland

and

National Museum of Natural History, B.Khmelnicki 15, 01030 Kiev, Ukraine leonid.rekovets@up.wroc.pl

Keywords: Insectivore mammals; Neogene; Quaternary; Eastern Europe

Submission: 27 May 2015 Acceptance: 2 February 2016

\section{INTRODUCTION}

Research on Ukrainian fossil insectivore mammals had a relatively late start, in the late fifties of the twentieth century. At that time the first studies were carried out by Pidoplichko (1955, 1956), Topachevsky (1956, 1957a, 1957b, 1959) and Tatarinov (1958). Subsequently, many papers were published but knowledge on fossil Ukrainian insectivores is still incomplete.

Rzebik-Kowalska, Barbara and Rekovets, Leonid I. 2016. New data on Eulipotyphla (Insectivora, Mammalia) from the Late Miocene to the Middle Pleistocene of Ukraine. Palaeontologia Electronica 19.1.9A: 1-31

palaeo-electronica.org/content/2016/1428-eulipotyphla-from-ukraine 

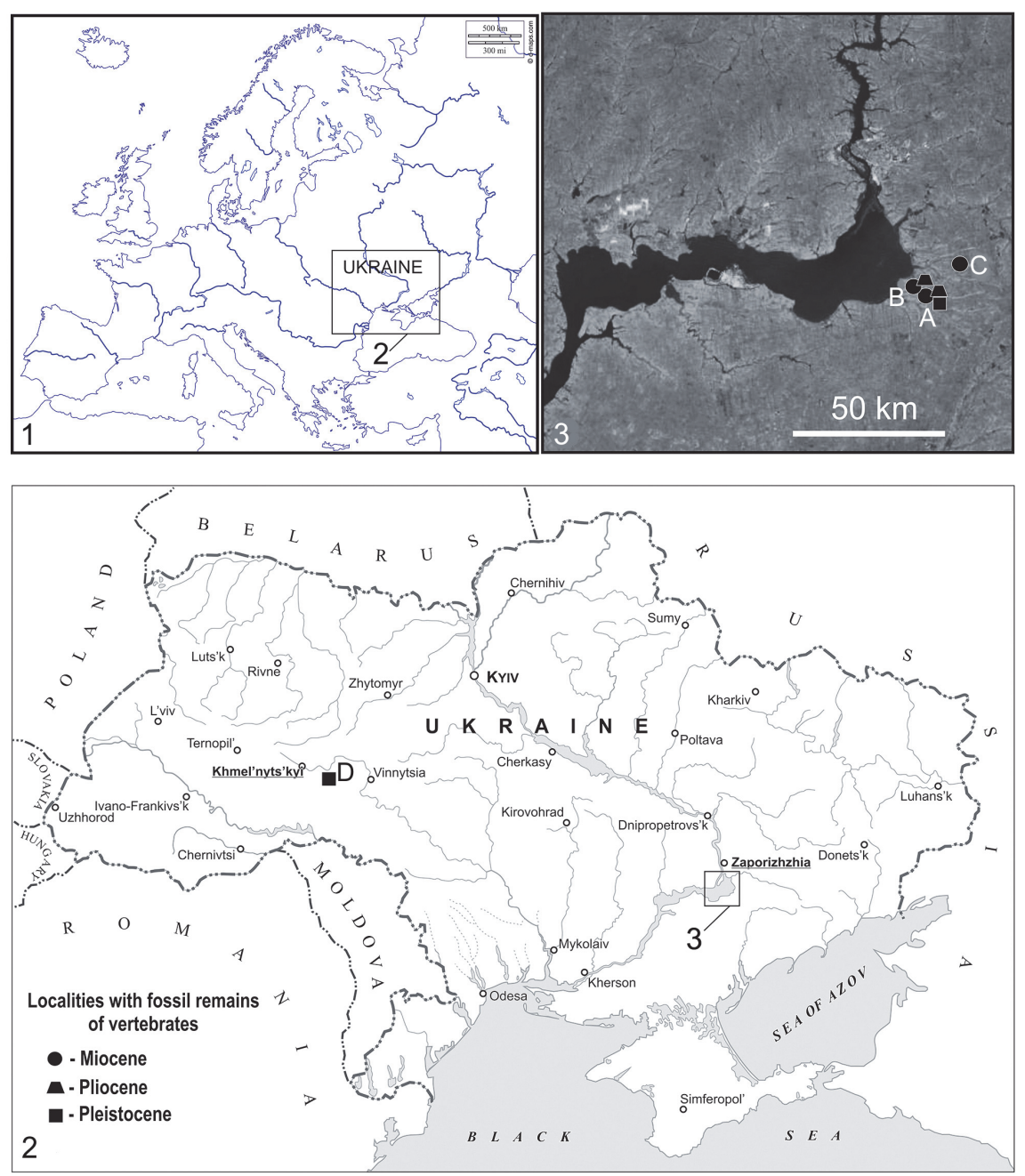

FIGURE 1. The Ukrainian localities in which insectivore mammals were studied. 1, Regional map of Europe indicating location of Ukraine (Inset, 2). 2-3, Ukraine Miocene to Pleistocene localities: Inset (3), Miocene localities (A-Popovo 3; B-Verkhnya Krynitsa 2; C-Lobkove), Pliocene localities (A-Popovo 2; B- Verkhnya Krynitsa 1), Plio/Pleistocene locality (A-Popovo 1); Pleistocene locality (A-Popovo 0; D- Medzhybozh).

So far 40 named species are available but only 25 (10 moles and 15 shrews) of 15 genera (four moles and 11 shrews) are well documented because their descriptions include measurements, systematic positions, localities and geological ages. Other taxa were described only at the genus level, some with question marks, cf. and aff. and others were listed in papers devoted to fossil localities and their faunas without any descriptions. These lists were usually copied from other publications of the same type without species verification, although some were wrongly identified and improbable in Ukrainian territory (e.g., the hedgehog Erinaceus europaeus Linnaeus, 1758, living today in western Europe or the shrew, Sorex arcticus Kerr,
1792, the range of which is limited to North America).

The present paper surveys non-described fossil insectivores from eight localities (Figure 1). Their geology and taphonomy are relatively well known (Pogorilets, 2014; Rekovets et al., 2014). Popovo 3, Verkhnya Krynitsa 2, Lobkove, Verkhnya Krynitsa 1, Popovo 2, Popovo 1 and Popovo 0 listed here are situated in the south-eastern Ukraine in the area of large marine basins of the Eastern Paratethys (Zaporozhskii region), on the left bank of the Dnieper river valley in its lower course. Layers of the Sarmatian (early Late Miocene) basin composed of limestones, clays, sands and other rocks occasionally entering the surface 
are covered by marine and continental layers of the Pliocene consisting of clays, sands gravels and also Pleistocene aleurites (fragments of rocks). These layers have long stratigraphic ranges dated from the Late Neogene (MN11) to the Early Pleistocene (Q1) and 1 to $2 \mathrm{~m}$ of thickness testifying that the localities were probably formed over a long period of time. The small mammals found there are represented by Eulipotyphla, Lagomorpha and Rodentia. The Talpidae and Soricidae are found in all localities, the Erinaceidae are rarer. Among Lagomorpha, the Lagomyidae are present almost everywhere but Leporidae are completely absent. The most common rodents are the Cricetidae, while the Muridae and Arvicolidae are rarer. Apart from small mammals, Mollusca, Osteichthyes, Amphibia, Reptilia (Chelonia, Lacertidae), Aves, Artiodactyla (Caprinae, Giraffidae) and Carnivora (Viveridae, Canidae) were also found (Rekovets and Pashkov, 2009).

The youngest Acheulean locality with alluvial sediments is Medzhybozh (early Middle Pleistocene, Q3). It is situated in western Ukraine on the left bank of the southern Bug River in Letichevskiy District and Khmielnitskaya Province (Rekovets, 2001). Remains of mammals were found there in alluvial deposit. It is about $1.5 \mathrm{~m}$ thick and covered by loesses and fossil soil, the thickness of which reaches $8 \mathrm{~m}$ (Pogorilets, 2014).

\section{METHODS}

Measurements of specimens were taken according to de Jong (1988) for Erinaceidae, and according to Hutchison (1974) and Reumer (1984) for Talpidae and Soricidae, respectively. Homologous elements (e.g., right first lower molar $\mathrm{m} 1$ or right humerus) were used to represent the minimum number of individuals (MNI). Soricidae teeth $(I 1, \mathrm{i} 1, \mathrm{a} 1)$ were measured along their buccal sides, all other teeth on their occlusal surfaces. The specimens described are housed in the collection of the Palaeontological Museum, National Museum of Natural History, National Academy of Sciences of Ukraine, in Kiev.

Abbreviations. $\mathrm{n}=$ number of specimens, $\mathrm{L}=$ maximum length, $\mathrm{W}=$ maximum width, $\mathrm{H}=$ maximum height, $\mathrm{L}$ trig. = length of trigonid, $\mathrm{L}$ tal. = length of talonid and DW = width of humerus diaphysis.

\section{SYSTEMATIC PALAEONTOLOGY}

\author{
Class MAMMALIA Linnaeus, 1758 \\ Superorder INSECTIVORA sensu Novacek, 1986
}

\author{
Order EULIPOTYPHLA Waddell, Okada and \\ Hasegawa, 1999 \\ Family ERINACEIDAE Fischer, 1814 \\ Subfamily GALERICINAE Pomel, 1848 \\ Genus SCHIZOGALERIX Engesser, 1980 \\ Schizogalerix sp. \\ Figure 2.1-2.5
}

Material. Popovo 3 (MN11), right P4, left $\mathrm{m} 1$, right $\mathrm{m} 2 . \mathrm{MNI}=1$. Catalogue number 29/III/1. Verkhnya Krynitsa 2 (MN11/MN12), left m1, left buccal fragment of $\mathrm{P} 4$, right $\mathrm{m} 2 . \mathrm{MNI}=1$. Catalogue number 29/2/1.

Description. The anterior and posterior sides of the P4 (Figure 2.1) are almost straight (not concave as typical for an upper P4). Its parastyle is vestigial in the tooth from Popovo 3 and slightly larger (in the shape of the cingulum cuspule) in Verkhnya Krynitsa 2. The paracone of P4 is strong, its protocone is also strong and larger than the hypocone. Cingula are absent except for anterobuccal and posterior ones. The $\mathrm{m} 1$ (Figure 2.2-4) has a clear paraconid and massive metaconid standing slightly anterior to the protoconid. The posterior cingulid is connected with the posterior arm of the entoconid and the hypoconid. The rather narrow anterior cingulid continues to the buccal side and finishes below the protoconid/ hypoconid valley. The $\mathrm{m} 2$ (Figure 2.5 ) is similar but smaller.

Measurements. See Table 1.

Systematic Position and Distribution. The relatively small size of the teeth indicates that they belong to Galericinae hedgehogs. In Europe the subfamily is comprised of seven genera. These include the Miocene (MN2/MN3-MN9 or MN10) Galerix Pomel, 1848 (Murelaga et al. 2004; van den Hoek Ostende and Furió, 2005), Lantanotherium Filhol, 1888 (MN3/MN4- MN11, van den Hoek Ostende et al., 2005) as well as the rare early Middle Miocene (MN3) Riddleria van den Hoek Ostende, 2003 and the Late Miocene Deinogalerix Freudenthal, 1972 and Apulogalerix Masini and Fanfani, 2013. Two genera - Parasorex von Meyer, 1865 (MN7+8-MN14, van den Hoek Ostende, 2001) and Schizogalerix Engesser, 1980 (MN5MN15, Doukas, 2005) are also recorded from the Early Pliocene.

A comparison of Ukrainian hedgehog teeth with those of Riddleria is difficult because the lower molars of the latter form are damaged. The detailed morphology of their posterior walls is unclear and their measurements imprecise. Moreover, upper teeth characteristic of the genus Riddleria are absent in Ukrainian material (except for 


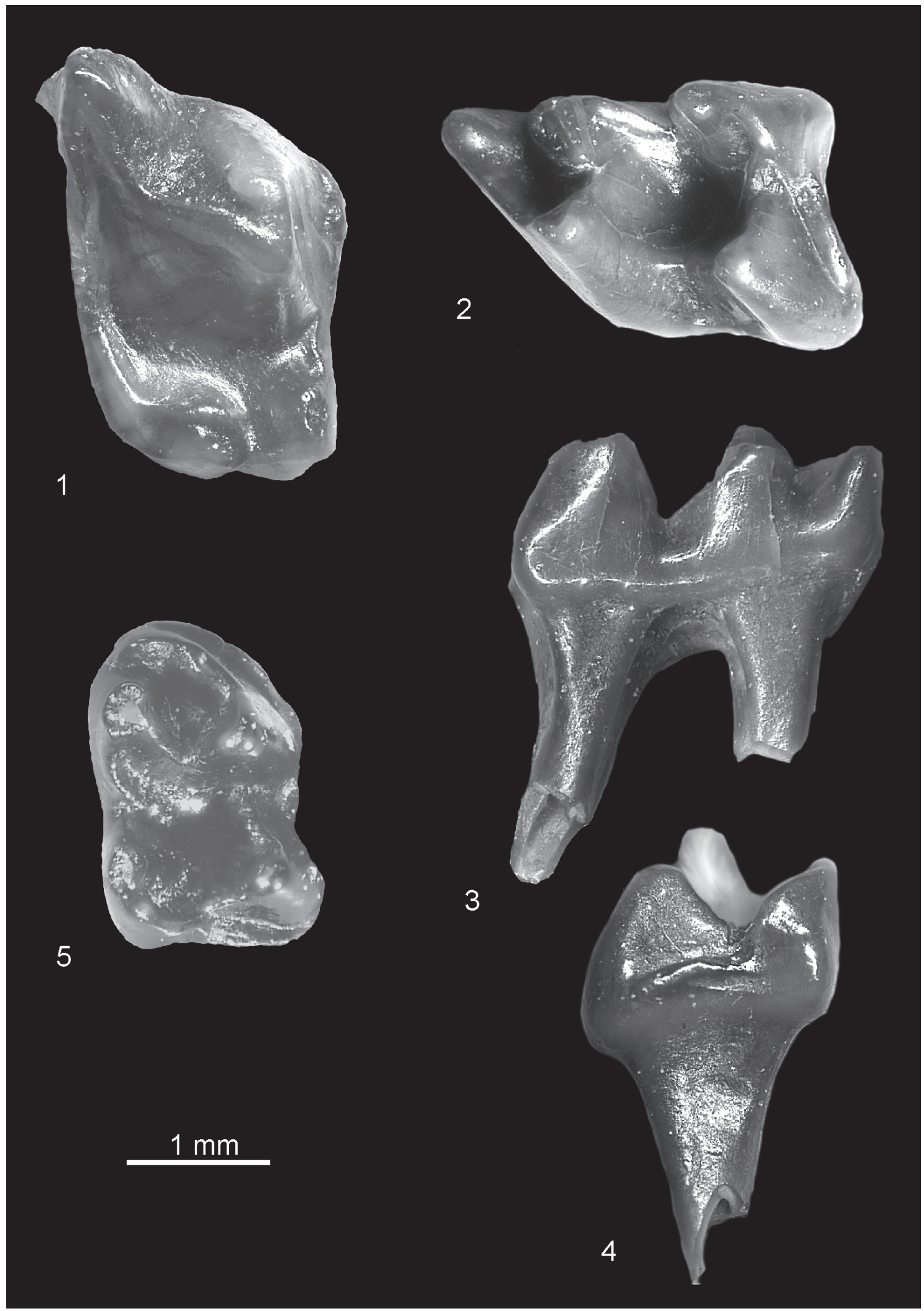

FIGURE 2. Schizogalerix sp. from Popovo 3 (1) and Verkhnya Krynitsa 2 (2-5). 1, right P4, occlusal view (catalogue number 29/III/1/1). (2-4) left m1; 2, occlusal; 3, lingual; 4, posterior view (c.n. 29/2/1/1); 5, right m2; occlusal view (c.n. 29/2/1/2). 
TABLE 1. Dimensions (in $\mathrm{mm}$ ) of Schizogalerix species.

\begin{tabular}{|c|c|c|c|c|c|c|}
\hline & & $\begin{array}{l}\text { Schizogalerix } \\
\text { sp. } \\
\text { Popovo } 3 \\
\text { Ukraine } \\
\text { MN11 }\end{array}$ & $\begin{array}{l}\text { Schizogalerix } \\
\text { sp. } \\
\text { Verkhnyaya } \\
\text { Krinitsa 2 } \\
\text { Ukraine } \\
\text { MN11/MN12 }\end{array}$ & $\begin{array}{c}\text { Schizogalerix sarmaticum } \\
\text { Buzhor } 1 \\
\text { the Republic of Moldova } \\
\text { MN9 } \\
\text { Rzebik-Kowalska and Lungu } \\
\text { (2009) }\end{array}$ & $\begin{array}{l}\text { Schizogalerix cf. } \\
\text { sarmaticum } \\
\text { Mikhailovka } 1 \\
\text { Ukraine } \\
\text { MN10 } \\
\text { Rzebik-Kowalska } \\
\text { and Nesin (2010) }\end{array}$ & $\begin{array}{c}\text { Schizogalerix } \\
\text { sarmaticum } \\
\text { Frunzovka } 2 \\
\text { Ukraine } \\
\text { MN11 } \\
\text { Rzebik-Kowalska } \\
\text { and Nesin (2010) }\end{array}$ \\
\hline $\mathrm{P} 4$ & L bucc. & 2.29 & 2.28 & 2.30 & - & $1.19-1.33, n=2$ \\
\hline \multirow[t]{5}{*}{$\mathrm{m} 1$} & L & 2.87 & 2.74 & $3.02-3.06, n=3$ & 2.59 & $2.66-2.82, n=3$ \\
\hline & $\mathrm{L}$ trig. & 1.63 & 1.57 & - & - & - \\
\hline & $\mathrm{L}$ tal. & 1.26 & 1.19 & - & - & - \\
\hline & L trig. - L. tal. & 0.37 & 0.38 & - & - & - \\
\hline & W & 1.79 & 1.80 & $1.82-1.94, n=4$ & 1.76 & $1.70-1.80, n=3$ \\
\hline \multirow[t]{5}{*}{$\mathrm{m} 2$} & L & 2.51 & 2.29 & $2.64-2.78, n=2$ & 2.34 & $2.30-2.35, n=2$ \\
\hline & $\mathrm{L}$ trig. & 1.41 & 1.29 & - & - & - \\
\hline & $\mathrm{L}$ tal. & 1.11 & 0.99 & - & - & - \\
\hline & $\mathrm{L}$ trig. - $\mathrm{L}$ tal. & 0.30 & 0.30 & - & - & - \\
\hline & W & 1.66 & 1.51 & $1.60-1.64, n=2$ & 1.56 & $1.65 ; 1.65, n=2$ \\
\hline
\end{tabular}

P4 which in Riddleria is fragmentary). So far Riddleria is known only from its type locality in Spain and dated to the early Middle Miocene; its presence in Ukraine is improbable. Even more unlikely are the very large representatives of the genus Deinogalerix and small representatives of the genus Apulogalerix. They are not found beyond the Gargano Peninsula (Italy). Also, the lower molars (m1 and m2) of Apulogalerix lack a connection between the posterior arm of the hypocone and posterior cingulid.

Lanthanotherium species have massive teeth, the metaconid of their $\mathrm{m} 1$ stands in front of the protoconid, the entocristid of $\mathrm{m} 1$ and $\mathrm{m} 2$ extends anteriorly and the trigonids of their lower molars (m1 and $\mathrm{m} 2$ ) are significantly longer than the talonids. The Ukrainian molars from Popovo 3 and Verkhnya Krynitsa 2 are not very heavy, the metaconid of their m1 stands slightly anteriorly in comparison with the protoconid, and their trigonids are not much longer than talonids. In the $\mathrm{m} 1$ the difference between the trigonid and talonid lengths equals $0.37-0.38 \mathrm{~mm}(\mathrm{n}=2)$ and in $\mathrm{m} 2$ it is $0.30 \mathrm{~mm}(\mathrm{n}=2)$. In Lanthanotherium sansaniense (Lartet, 1851) this difference equals $0.76-0.78 \mathrm{~mm}$ in $\mathrm{m} 1$ and $0.35-$ $0.41 \mathrm{~mm}$ in $\mathrm{m} 2$ (calculated from minimum, average and maximum lengths of these teeth cited by Baudelot, 1972). In Parasorex species there is no connection between the posterior cingulids and the posterior arm of the entoconid in lower molars while in teeth from Popovo 3 and Verkhnya Krynitsa 2 this connection is very clear. It is also present in the molars of Schizogalerix and just this character allowed the inclusion of Ukrainian molars to the genus Schizogalerix.

According to van den Hoek Ostende (2001) a connection between the posterior cingulid and the posterior arm of the entoconid is also visible in populations of Galerix symeonidisi Doukas, 1983 from Aliveri (Greece, MN4) and from several localities in Germany (MN4, MN5) (Doukas, 1986; Ziegler and Fahlbusch, 1986; Prieto and Rummel, 2009) but it is not present in younger (Middle and Late Miocene) species of this genus (compare with van den Hoek Ostende and Doukas, 2003).

So far more than 10 named species of Schizogalerix have been described in Europe (RzebikKowalska and Lungu, 2009). One of them, S. sarmaticum (Lungu, 1981) was cited from Ukraine [Mikhailovka 1 (MN10) and Frunzovka 2 (MN11)]. However, the specimens described above cannot belong to $S$. sarmaticum because the P4 of the latter form is characterized by a large parastyle (vestigial in the specimen from Popovo 3 and Verkhnya Krynitsa 2) and very long entoconids and entostylids in lower molars (entostylids are lacking in Popovo 3).

All species of the genus Schizogalerix are more or less similar in size (Rzebik-Kowalska, 2009). From the morphological point of view the P4 from Ukrainian localities is very similar (by its almost straight anterior and posterior sides of the crown) to the P4 of $S$. anatolica from Turkey (MN7+8, Engesser, 1980) and especially to P4 of S. moedlingensis from Austria (MN11, Rabeder, 1973). The age and geographical distribution of the Ukrainian specimens are closer to the age and dis- 
tribution of S. moedlingensis. However, material from Popovo 3 and Verkhnya Krynitsa 2 is too poor to allow species identification.

Representatives of the genus Schizogalerix were collected in neighboring countries such as the Republic of Moldova (Lungu, 1981; Rzebik-Kowalska and Lungu, 2009; Lungu and Rzebik-Kowalska, 2011), Romania (Rzebik-Kowalska, 2005) and Slovakia (Fejfar and Sabol, 2005) as well as in other European countries (Rzebik-Kowalska, 2009), Asia minor, Engesser, 1980; Sen, 1990; Selänne, 2003; de Bruijn et al., 2006; Furió et al., 2014), China (Qiu and Storch, 2005) and North Africa (Algeria and Morocco; Engesser, 1980; Stoetzel, 2013).

Family TALPIDAE Fischer, 1814

Subfamily DESMANINAE Thomas, 1912

Genus MYGALINIA Schreuder, 1940

cf. Mygalinia hungarica (Kormos, 1913)

Figure 3.1

Material. Verkhnya Krynitsa 2 (MN11/MN12), left $\mathrm{m} 2 . \mathrm{MNI}=1$. Catalogue number 29/2/2.

Description. The tooth (Figure 3.1) is more massive than mole teeth of the subfamily Talpinae. Its trigonid and talonid are more or less of the same size, the oblique cristid reaches the tip of the metaconid and the re-entrant valley is deep. The cingulid is protruded and surrounds the anterior, buccal and posterior sides of the tooth. The lingual cingulid is absent, the parastylid and entostylid are present.

Measurements. See Table 2.

Systematic Position and Distribution. The combination of such characters as massiveness, the presence of protruded cingulids, a large trigonid, parastylid and entostylid indicate that the tooth represents the second lower molar (m2) belonging to the subfamily Desmaninae, and its small size suggests the genus Mygalinia Schreuder, 1940. The teeth of small Storchia Dahlmann, 2001 known from Germany (MN11-MN15) have much more narrow lower molars and those of Ruemkelia (even the smallest species) are larger (see Table 2).

The genus Mygalinia is represented only by one species M. hungarica (Kormos, 1913). It was described as Galemys hungaricus Kormos, 1913 from Polgárdi 2 and 4 in Hungary (MN 13) and listed later by Guerin and Mein (1971) in several localities of France (Soblay [MN10], Mollon [MN11], Lobrieu [MN11], Lissieu [MN13], Hauterives [MN14], Hautimagnes [MN14]). As the studied material is very scarce (one tooth) and the description of the typical specimens (Kormos,
1913) is limited, the $\mathrm{m} 2$ from Verkhnya Krynitsa 2 is tentatively identified as cf. M. hungarica.

\section{Genus RUEMKELIA Rzebik-Kowalska and Pawłowski, 1994}

Nomenclatural Comment. The genus Dibolia was established by Latreille (1829) for a leaf beetle. In 1985 C.G. Rümke introduced the generic name Dibolia for Desmaninae moles and indicated $D$. dekkersi n. sp. as the type species. Rzebik-Kowalska and Pawłowski (1994), after contacting C.G. Rümke, proposed the new name to replace the junior homonym. However, some authors (e.g., Hutterer, 1995) are of the opinion that Archaeodesmana Topachevsky and Pashkov, 1983 is available as a replacement name for Dibolia Rümke, 1985. As the Archaeodesmana type species, Desmana pontica Schreuder, 1940 may not be congeneric with "Dibolia" dekkersi, we prefer to use the name Ruemkelia until a revision of the systematics of Desmaninae is done.

Ruemkelia sp.

Figure 3.2

Material. Verkhnya Krynitsa 2 (MN11/MN12), fragment of left m2. MNI=1. Catalogue number 29/2/3.

Description. The tooth (Figure 3.2) is damaged with an anterior fragment of its trigonid (paraconid) lacking. The morphology of its preserved part is similar to the complete $\mathrm{m} 2$ morphology from the same locality (Verkhnya Krynitsa 2) described as cf. Mygalinia hungarica but it is larger.

Measurements. See Table 2.

Systematic Position and Distribution. As mentioned above the Desmaninae tooth (fragment of $\mathrm{m} 2$ ) is similar to the $\mathrm{m} 2$ of cf. Mygalinia hungarica but it is wider and must have been longer. However, it cannot represent the $\mathrm{m} 1$ of $M$. hungarica because its width is too big $(1.75 \mathrm{~mm})$. According to Kormos (1913) the width of $\mathrm{m} 1$ of $M$. hungarica equals only $1.40-1.50 \mathrm{~mm}, \mathrm{n}=$ ?. On the other hand the width of the above described tooth is typical of $\mathrm{m} 2$ of Ruemkelia. As almost all species of this genus are similar in size, more precise identification of this tooth is impossible.

So far Ruemkelia sp. was cited from three Late Miocene Ukrainian localities (Mikhailovka 1 [MN10], Mikhailovka 2 and Frunzovka 2 [MN11]). Only in one locality (Mikhailovka 1) a second lower molar (m2) was found.

The different species of Ruemkelia were widely distributed in Europe from Spain (van den Hoek Ostende and Furió, 2005) to Greece (Doukas, 2005) and the Republic of Moldova (RzebikKowalska and Lungu, 2009) and dated from the 


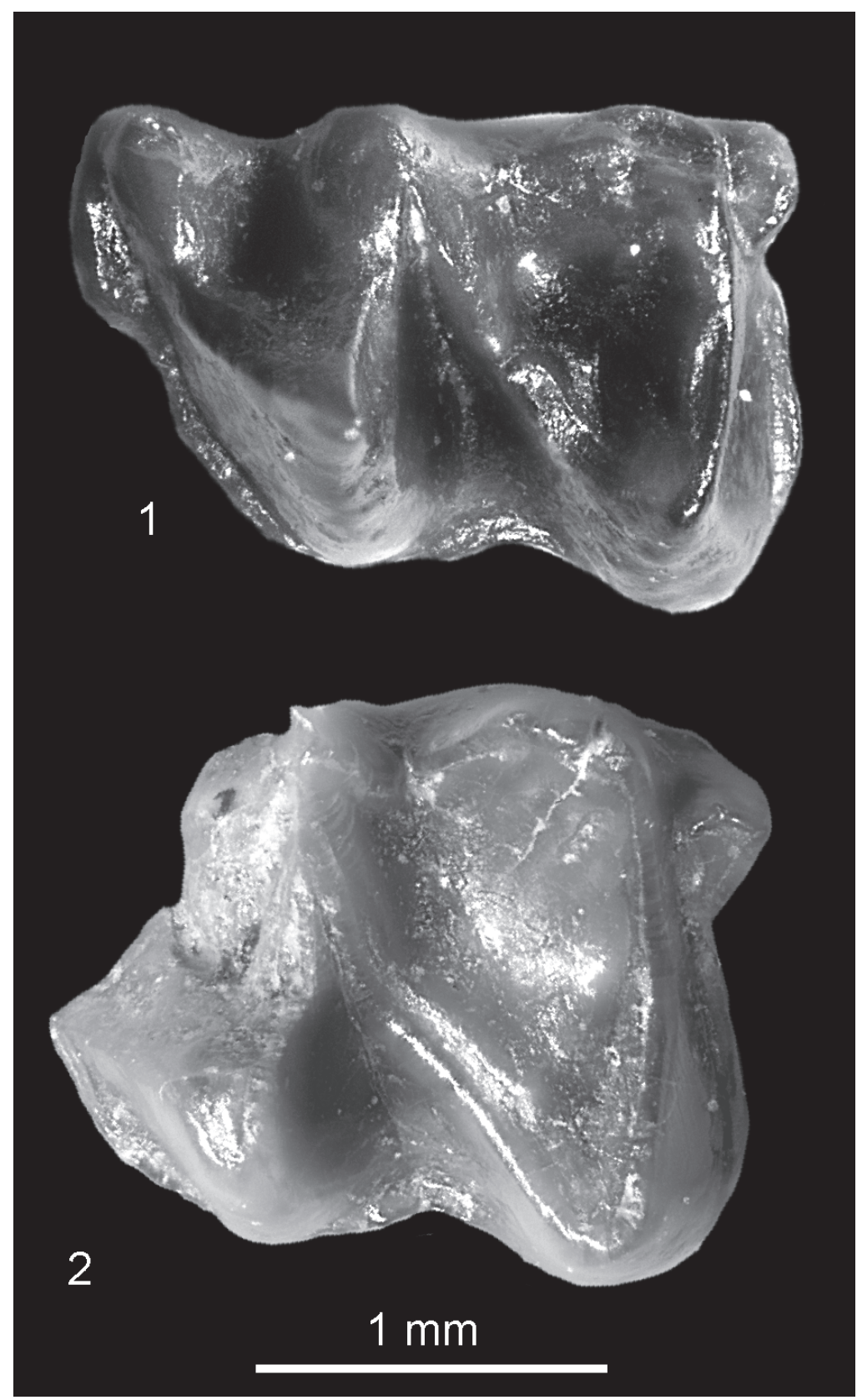

FIGURE 3. 1, cf. Mygalinia hungarica from Verkhnya Krynitsa 2, left m2, occlusal view (c.n. 29/2/2/1); 2, Ruemkelia sp. from Verkhnya Krynitsa 2, fragment of left m2, occlusal view (c.n. 29/2/3/1).

TABLE 2. Dimensions (in mm) of lower teeth of Mygalinia, Storchia and Ruemkelia (except of R. vinea and R. dekkersi).

\begin{tabular}{|c|c|c|c|c|c|c|c|c|c|}
\hline & & $\begin{array}{c}\text { cf. Mygalinia } \\
\text { hungarica } \\
\text { Verkhnyaya } \\
\text { Krinitsa 2 } \\
\text { Ukraine } \\
\text { MN11/MN12 }\end{array}$ & $\begin{array}{c}\text { Mygalinia } \\
\text { hungarica } \\
\text { Polgardi } 2 \\
\text { and } 4 \\
\text { Hungary } \\
\text { MN13 } \\
\text { Kormos } 1913\end{array}$ & $\begin{array}{l}\text { Storchia vedrevis } \\
\text { Wölfersheim } \\
\text { Germany } \\
\text { MN11-N15 } \\
\text { Dahlmann } 2001\end{array}$ & $\begin{array}{c}\text { Ruemkelia sp. } \\
\text { Verkhnyaya } \\
\text { Krinitsa } 2 \\
\text { Ukraine } \\
\text { MN11/MN12 }\end{array}$ & $\begin{array}{c}\text { Ruemkelia sp } \\
\text { Mikhailovka } 1 . \\
\text { Ukraine } \\
\text { MN10 } \\
\text { Rzebik- } \\
\text { Kowalska and } \\
\text { Nesin } 2010\end{array}$ & $\begin{array}{c}\text { Ruemkelia vinea } \\
\text { Dorn-Dürkheim, } \\
\text { Kohfidisch } \\
\text { Germany, Austria } \\
\text { MN11 } \\
\text { Rümke } 1985\end{array}$ & $\begin{array}{c}\begin{array}{c}\text { Ruemkelia } \\
\text { dekkersi }\end{array} \\
4 \text { localities } \\
\text { Greece } \\
\text { MN13, MN14 } \\
\text { Rümke } 1985\end{array}$ & $\begin{array}{c}\text { Ruemkelia } \\
8 \text { species } \\
\text { Europe and } \\
\text { Asiatic Turkey } \\
\text { MN12-MN15 } \\
\text { Rümke } 1985\end{array}$ \\
\hline \multirow[t]{2}{*}{$\mathrm{m} 2$} & $L$ & 2.12 & $2.00-2.10, n=4$ & 2.26; holot & * & $2.21-2.48$ & 2.19-2.36, & 2.09 & 2.1 \\
\hline & W & 1.30 & $1.30-1.40, n=4$ & 1.16 & 1.74 & $1.49-1.77, n=10$ & $1.44-1.74, n=14$ & $1.50-179, n=47$ & $1.59-1.95, n=161$ \\
\hline
\end{tabular}


Late Miocene to the early Late Pliocene (MN9MN16).

\section{Genus DESMANA Gueldenstaedt, 1777 Desmana sp.}

Figures 4.1-4.7, 5.1-5.6, 6.1

Material. Verkhnya Krynitsa 1 (early MN16), the left ?:2 and a fragment of the right mandible damaged in its anterior and lower side (without process) with damaged $\mathrm{p} 4 . \mathrm{MNI}=1$. Catalogue number 29/1/4. Popovo 2 (late MN16), left C, left $P 2$, left P4, right M1, left ?i3, left ?p2, two left m3 (one damaged). $\mathrm{MNI}=2$. Catalogue number 29/II/ 4. Popovo 1 (MN16/MN17), left M1, fragment of right mandible with $\mathrm{m} 1-\mathrm{m} 3$, left $\mathrm{m} 1 . \mathrm{MNI}=1$. Catalogue number 29///4.

Description. According to Rümke (1985, p. 44) in the genus Desmana "it is difficult, often even impossible, to distinguish the 12 from the 13 ." The tooth from Verkhnya Krynitsa 1 is most likely the 12 (Figure 4.1-2). The cross-section of its crown is elliptical, the buccal side is convex and the lingual side is flat. The cusp is situated more or less in the middle of the crown. Two medial crests start from its tip: the posterior crest (the posterocrista) is longer and sharper. The buccal side is surrounded by a wide and flat cingulum. The root of the tooth is straight and heavy. The C (Figure 4.3-4) is also elliptical with one high cusp situated more or less in the center of the crown. The anterocrista is slightly shorter and steeper than the posterocrista which is also longer. The buccal side of the crown is slightly convex, the lingual side almost flat. The wide and flat cingulum is visible on its lingual side. Small cingular bulges are present on the anterior and posterior sides of the tooth. There are two rather heavy and divergent roots. The P2 (Figure 4.5) is fixed in a small part of the jaw. It is relatively large and its crown is sturdy. It is wider posteriorly than anteriorly. The crests running from the tip of the cusp are not very sharp. The buccal side of the crown is convex, the antero-lingual rather flat and posterolingual concave. The anterior and posterior ends of the crown are rounded. A wide and protruding cingulum runs around the crown except for the short buccal part between the roots. The tooth has two heavy, divergent roots. The P4 (Figure 4.6) has a sub-triangular outline. The antero-buccal and antero-lingual sides are convex, the postero-buccal and postero-lingual parts are concave. The paracone anterocrista is obtuse, the parastyle is not large. The posterocrista bends slightly to the buccal side and forms a small cusp, namely the metacone. The protocone is well individualized and separated from the paracone by a valley: small and shallow in the anterior and large and deep in the posterior part of the tooth. The hypocone is a clear cusp situated posteriorly to the protocone. The wide and protruding cingulum surrounds the tooth except for the protocone. The postero-lingual cingulum bears a small cuspule, the hypocone. The tooth has three roots. The M1 (Figure 4.7) has a deeply divided mesostyle, well individualized parastyle separated from the paracone by a valley and connected to the protoconule by a short crest. The accessory cusp is situated between the protocone and metaconule (?hypocone). The tooth has part of the anterior (between the paracone and protoconule), antero-labial and posterior cingula. The postero-labial cingulum is damaged. The root part of the tooth is damaged and only a trace of one root is present.

The crown of ?i3 (Figure 5.1-2) is low and strongly asymmetrical. Its buccal side is narrow and almost flat, the lingual one is wide and concave. Only the tip of the cusp is inflated. The antero and posterocristids are blunt. The anterior, lingual and posterior cingulids are present. The tooth has one root. The ?p2 (Figure 5.3-4) is damaged on its tip of the cusp as well as in the postero-lingual side which was rather concave. It has an elliptical crosssection. It is rather stout with its buccal side convex and its antero-lingual side flat. Its only cusp is situated in the middle of the crown, and its anterior crest is moderately sharp. The tooth is pointed towards the anterior and rounded in the posterior sides. The cingulid is well developed, more protruding in the anterior than in the postero-buccal side. There are two rather heavy roots. The small p3 is completely damaged. It has one root. The p4 is a heavy compact tooth. Its postero-lingual side is damaged. The damaged talonid was rather narrow, open on its buccal side. The buccal side of the tooth is strongly convex, the lingual side less convex. As the posterocristid is also damaged, the presence of a metaconid cannot be confirmed. The tooth has anterior, lingual and posterior (partially damaged) protruding cingulids (the buccal one is damaged). It has two heavy rounded roots. The lower molars m1-m3 (Figure 6.1) are typical for desmans. They are heavy and have sturdy obtuse cusps. Their oblique cristids are long and end near the tip of the metaconid. Their cingulids are wide. In the $\mathrm{m} 1$ (Figure 5.5) and $\mathrm{m} 2$ they are present on anterior, buccal and posterior sides. On the $\mathrm{m} 3$ (Figure 5.6) the cingulid occurs on the anterior and buccal sides reaching the protoconid/hypoconid valley. In the $\mathrm{m} 2$ and $\mathrm{m} 3$, the anterior cingulids widens in the antero-lingual corner and forms a kind of 


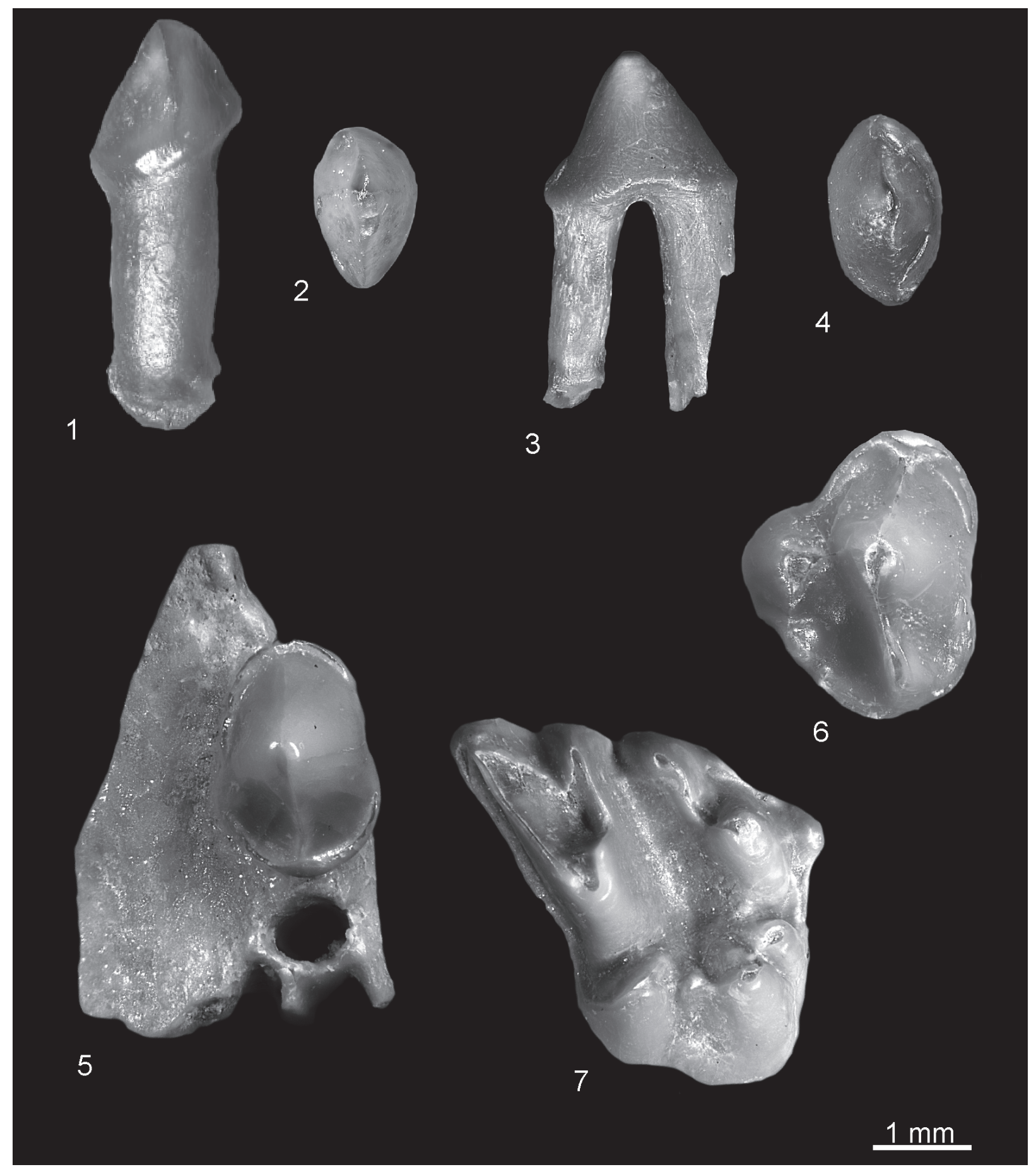

FIGURE 4. Desmana sp. from Verkhnya Krynitsa 1 (1-2) and from Popovo 2 (3-7). Left ?I2, 1, buccal; 2, occlusal view (c.n. 29/1/4/1). Left C: 3, buccal; 4, occlusal view (c.n. 29/II/4/1). 5, Left P2, occlusal view (c.n. 29/II/4/2). 6, Left P4, occlusal view (c.n. 29/II/4/3). 7, Right M1, occlusal view (c.n. 29/II/4/4). 


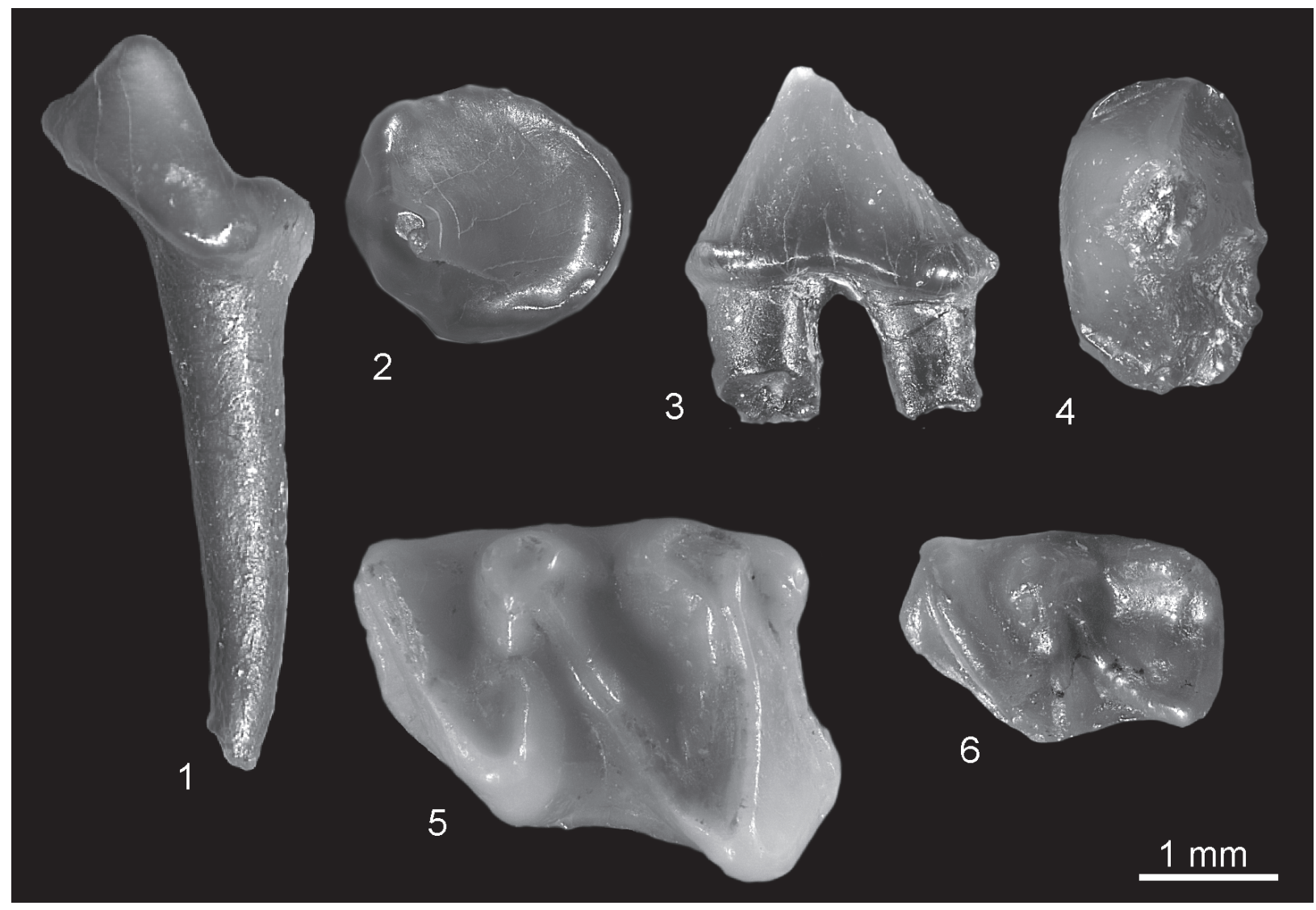

FIGURE 5. Desmana sp. from Popovo 2 (1-4 and 6) and Popovo 1 (5). Left ?i3: 1, buccal, 2, occlusal view (c.n. 29/II/ 4/5). Left p2: 3, buccal; 4, occlusal view (c.n. 29/II/4/6). 5, Left m1, occlusal view (c.n. 29/l/4/1). 6, Left m3, occlusal view (c.n. 29/II/4/7).

parastylid. The entostylid is present in the $\mathrm{m} 1$ and $\mathrm{m} 2$. The teeth have two heavy roots.

Measurements. See Tables 3 and 4.

Systematic Position and Distribution. The identification of Desmana species is difficult because some of their diagnoses are based on the morphology of $\mathrm{p} 4$ (absent in the described material with the exception of one damaged specimen from Verkhnya Krynitsa 1) and on the mutual size of antemolars in upper and lower jaws (mostly isolated teeth occur in the Ukrainian material) and the number of antemolar roots. Molars, comparatively frequent in fossil material, are in all forms of Desmaninae very uniform and useless in specific identification. For this reason only some speculation based on the overall size of all teeth present in the collection and their geological age could be helpful. However, the size of specimens is not always reported. The monograph of Rümke (1985) does not provide incisor dimensions and in Ukrainian papers (Pashkov and Topachevsky, 1990; Topachevsky and Pashkov, 1990) there are no measurements of molars.
So far four species of the genus Desmana were described from Ukraine. These include $D$. jalpugensis Pashkov and Topachevsky, 1990 and $D$. kujalnikensis Pashkov and Topachevsky, 1990 found in Late Pliocene (MN16) localities and $D$. nogaica Topachevsky and Pashkov, 1990 and $D$. gureevi Topachevsky and Pashkov, 1990 known from the Early Pleistocene (former late Late Pliocene, MN17). Rzebik-Kowalska and Nesin (2010) cited $D$. cf. nehringi Kormos, 1913 from a locality dated to the Late Miocene (MN13) and Rekovets and Pashkov (2009) mentioned D. moldavica Pashkov and Topachevsky, 1990 (the Early/Late Pliocene boundary, MN15/MN16), Galemys cf. kormosi (beginning of the Late Pliocene, early of MN16) and D. cf. jalpugensis (middle of MN16).

Several species of Desmana were also described from neighboring countries: $D$. verestchagini Topachevsky, 1961 from Russia (MN14), $D$. moldavica (MN16) and $D$. meridionalis Topachevsky and Pashkov, 1990 (Early Pleistocene, former MN17) from the Republic of Moldova, D. thermalis Kormos, 1930 (Pleistocene, Early Bih- 
TABLE 3. Dimensions (in mm) of upper teeth of Desmana species ( ${ }^{*}$ specimen a little damaged; ${ }^{* *}$ calculated by author from minimum - maximum measurements; ${ }^{* * *}$ dimension made by author from picture, plate $1,1, p .109$, Rümke, 1985).

\begin{tabular}{|c|c|c|c|c|c|c|}
\hline & & $\begin{array}{c}\text { Desmana sp. } \\
\text { Verkhnyaya } \\
\text { Krinitsa } 1 \\
\text { Ukraine } \\
\text { beginning of } \\
\text { MN16 }\end{array}$ & $\begin{array}{c}\text { Desmana sp. } \\
\text { Popovo } 2 \\
\text { Ukraine } \\
\text { end of MN16 }\end{array}$ & $\begin{array}{c}\text { Desmana sp. } \\
\text { Popovo } 1 \\
\text { Ukraine } \\
\text { MN16/MN17 }\end{array}$ & $\begin{array}{c}\text { Desmana kujalnikensis } \\
\text { Cherevichnoe } \\
\text { Ukraine } \\
\text { MN16 } \\
\text { Pashkov and } \\
\text { Topachevsky } 1990\end{array}$ & $\begin{array}{c}\text { Desmana thermalis } \\
\text { Tegelen; Betfia } 2 \\
\text { The Netherlands; } \\
\text { Romania } \\
\text { MN17, Q1 } \\
\text { Rümke 1985 }\end{array}$ \\
\hline \multirow[t]{2}{*}{$? 12$} & $\mathrm{~L}$ & 1.64 & - & - & - & - \\
\hline & W & 1.03 & - & - & - & - \\
\hline \multirow[t]{2}{*}{$\mathrm{C}$} & L & - & 1.97 & - & - & $1.98-2.49, n=14$ \\
\hline & W & - & 1.21 & - & - & $1.39-1.63, n=14$ \\
\hline \multirow[t]{3}{*}{$\mathrm{P} 2$} & L & - & 2.38 & - & $2.15 ; 2.40, \mathrm{n}=2$ & $2.32-2.61, n=12$ \\
\hline & W & - & 1.74 & - & $1.60 ; 1.70, n=2$ & $1.59-1.90, n=12$ \\
\hline & $W / L$ & - & 0.73 & - & $0.74 ; 0.71$ & $0.68-0.73$ * * \\
\hline \multirow[t]{3}{*}{ P4 } & L & - & 2.84 & - & $2.90 ; 3.10, n=2$ & $2.68-3.27, n=14$ \\
\hline & W & - & 2.38 & - & $2.50 ; 2.80, n=2$ & $2.25-2.75$ \\
\hline & W/L & - & 0.84 & - & $0.86 ; 0.90$ & $0.84^{* *}$ \\
\hline \multirow[t]{2}{*}{ M1 } & L & - & 3.96 & 4.09 & - & $3.66-4.20, n=13$ \\
\hline & W & - & 3.62 & 3.92 & - & $3.04-3.70, n=13$ \\
\hline
\end{tabular}

TABLE 4. Dimensions (in $\mathrm{mm}$ ) of lower teeth and humerus of Desmana species.

\begin{tabular}{|c|c|c|c|c|c|c|c|}
\hline & & $\begin{array}{l}\text { cf. Desmana sp. } \\
\text { Verkhnyaya } \\
\text { Krinitsa } 2 \\
\text { Ukraine } \\
\text { MN11/MN12 }\end{array}$ & $\begin{array}{c}\text { Desmana sp. } \\
\text { Verkhnyaya } \\
\text { Krinitsa } 1 \\
\text { Ukraine } \\
\text { beginning of } \\
\text { MN16 }\end{array}$ & $\begin{array}{c}\text { Desmana sp. } \\
\text { Popovo } 2 \\
\text { Ukraine } \\
\text { end of MN16 }\end{array}$ & $\begin{array}{c}\text { Desmana sp. } \\
\text { Popovo } 1 \\
\text { Ukraine } \\
\text { MN16/MN17 }\end{array}$ & $\begin{array}{c}\text { Desmana } \\
\text { kujalnikensis } \\
\text { Cherevichnoe } \\
\text { Ukraine } \\
\text { MN16 } \\
\text { Pashkov and } \\
\text { Topachevsky } \\
1990\end{array}$ & $\begin{array}{c}\text { Desmana } \\
\text { thermalis } \\
\text { Tegelen } \\
\text { Betfia } 2 \\
\text { The Netherlands, } \\
\text { Romania } \\
\text { MN17, Q1 } \\
\text { Rümke 1985 }\end{array}$ \\
\hline \multirow[t]{2}{*}{ ?i3 } & $\bar{L}$ & - & - & 1.97 & - & - & - \\
\hline & W & - & - & 1.77 & - & - & - \\
\hline \multirow[t]{3}{*}{ ?p2 } & L & - & - & 2.30 & - & 2.20 & $1.92-2.40, n=17$ \\
\hline & W & - & - & 1.49 & - & - & $1.33-1.60, n=17$ \\
\hline & W/L & - & - & 0.64 & - & - & $0.67-0.69$ * * \\
\hline \multirow[t]{3}{*}{$\mathrm{p} 4$} & L & - & 2.27 & - & - & $2.25 ; 2.50, n=2$ & $1.99-2.63, n=20$ \\
\hline & w & - & $1.57^{*}$ & - & - & $1.60 ; 1.75, n=2$ & $1.48-1.87, n=20$ \\
\hline & $W / L$ & - & $0.69^{*}$ & - & - & $0.68 ; 0.76$ & $0.71-0.74$ * * \\
\hline \multirow[t]{2}{*}{$\mathrm{m} 1$} & L & - & - & - & $3.05^{*}-3.35$ & - & $2.67-3.61, n=14$ \\
\hline & W & - & - & - & $2.49-2.72$ & - & 2.11-2.76, n=14 \\
\hline \multirow[t]{2}{*}{$\mathrm{m} 2$} & L & - & - & - & 2.98 & - & $2.80-3.47, n=14$ \\
\hline & w & - & - & - & 2.12 & - & $2.10-2.60, n=14$ \\
\hline \multirow[t]{2}{*}{$\mathrm{m} 3$} & L & - & - & $2.39^{*}-2.42, n=2$ & 2.54 & - & $2.24-2.63, n=13$ \\
\hline & W & - & - & $1.42^{*}-1.59, n=2$ & 1.66 & - & $1.37-1.95, n=13$ \\
\hline \multicolumn{2}{|c|}{$\begin{array}{l}\mathrm{H} \text { of mandible } \\
\text { below } \mathrm{m} 2\end{array}$} & - & - & - & 4.86 & - & - \\
\hline \multirow[t]{2}{*}{ Humerus } & L & 17.36 & - & - & - & - & $16.67^{* * *}$ \\
\hline & DS & 3.22 & - & - & - & - & $2.70^{* * *}$ \\
\hline
\end{tabular}


arian) from Hungary as well as $D$. amutriensis Rădulescu, Samson and Ştiucă, 1989 (Early Pliocene, MN14, MN15) and D. radulescui Ştiucă, Petculescu and Arghir, 2003 (Late Pliocene, MN16) from Romania. However, for reasons mentioned above, many Ukrainian remains (mostly isolated teeth) of this genus were described as Desmana sp. or Desmaninae gen. et $\mathrm{sp}$. indet.

The majority of remains from Verkhnya Krynitsa 1 and Popovo 2 and 1 also represent isolated and damaged teeth and their inclusion into any species is unfeasible.

The remains described above could either belong to different species or to one species, especially since their size is more or less uniform and they were all collected in localities of similar age (between the Early/Late Pliocene boundary and the early Late Pliocene [MN15/MN16, middle of MN16]). Their detailed size and morphological comparison with all known forms of European Desmana indicates that they are smaller or have different proportions than those of $D$. jalpugensis, $D$. kujalnikensis, D. nogaica, D. gureevi, D. moldavica, $D$. meridionalis and $D$. radulescui. On the other hand, they are larger than remains of $D$. verestchagini, D. nehringi, D. inflata Rümke, 1985 and D. amutriensis.

As seen in Table 3 and Table 4 their size is close to the size of Desmana thermalis and $D$. kujalnikensis. However in morphology there are some differences between them (e.g., P4 from Popovo 2 has a well-developed hypocone, which is not very distinct in the P4 of $D$. thermalis and $D$. kujalnikensis). Concerning the age, Desmana from Popovo 2 (late MN16) is closer to $D$. kujalnikensis which is also from MN16, whereas $D$. thermalis is younger, its older specimens come from localities dated to MN17.

Rekovets and Pashkov (2009) listed three species of desmans from localities studied in this paper. Based on one fragment of mandible with p2-p4, they mentioned Desmana moldavica from Verkhnya Krynitsa 1 (early MN16). The p4 from the D. moldavica holotype measured by Pashkov and Topachevsky (1990) is slightly larger $(L=2.60 \mathrm{~mm}$, $\mathrm{W}=1.80 \mathrm{~mm}$ ) than the $\mathrm{p} 4$ from the same locality (see Table 3) and cited here as Desmana sp. The same authors mentioned Desmana cf. kormosi from Popovo 2. As they did not give any characters, dimensions or drawings of these specimens (P2, M3 and p4), a comparison with teeth described above is impossible. Besides, Rümke (1985) demonstrated that the species "kormosi" should be placed in the genus Galemys [G. kor- mosi (Schreuder, 1940)], not Desmana. However, teeth from Popovo 2 described in this paper are larger than any teeth of Galemys species, and they surely belong to Desmana.

One mandible (whole? or fragmentary?, with or without teeth and processes?) from Popovo 1 was classified by Rekovets and Pashkov (2009) as Desmana cf. jalpugensis. The $\mathrm{m} 1$ described in the present paper may also belong to this species. However, the lack of a description, measurements or drawing in the paper of Rekovets and Pashkov (2009) also excludes a comparison.

In this situation the scanty and badly preserved material of the large Desmaninae from Verkhnya Krynitsa 1, Popovo 2 and 1 are tentatively ascribed to Desmana sp.

The large number of species described from Europe and from Ukraine and its adjacent territories (some of them on the basis of scanty material) as well as the lack of knowledge on their individual, geographic and stratigraphic variation suggest that a review of the genus Desmana is badly needed.

\section{cf. Desmana sp. \\ Figure 6.2-6.3}

Material. Verkhnya Krynitsa 2 (MN11/MN12), left humerus. $\mathrm{MNI}=1$. Catalogue number 29/2/5.

Description. The humerus (Figure 6.2-3) is very slender. The pectoral process is long and the wedge-shaped area is not very well marked on its external side. The teres tubercle is rather long. The entepicondyle is broken. The elliptical entepicondylar foramen is large. The supratrochlear fossa is large and deep. The ectepicondyle is large. The olecranon fossa is shallow and the head is large.

Measurements. See Table 4.

Systematic Position. The humerus found in this locality belongs to the genus Desmana. Its preserved parts compared with homologues in $D$. moschata (Linnaeus, 1758) are morphologically identical. On the other hand, it is larger than the humerus of Mygalinia hungarica found in the same locality as well as larger than all known humeri of Ruemkelia, Galemys and of the oldest Desmana e.g., $D$. verestchagini (MN14). The DW of: $D$. verestchagini is $2.00 \mathrm{~mm}$; $D$. thermalis is $2.89 \mathrm{~mm}$; and G. kormosi is $2.22 \mathrm{~mm}$ (from plate 1, figures 1 3 , p. 109, Rümke, 1985). The length of the DW from Verkhnya Krynitsa 2 equals $3.22 \mathrm{~mm}$ and is closer to the length of the DW of $D$. thermalis. However, the last form is known only from localities dated to the Early Pleistocene.

So far no species of Desmana occurs earlier than the beginning of the Ruscinian (MN14) (the genus Desmana has not been found in sediments 


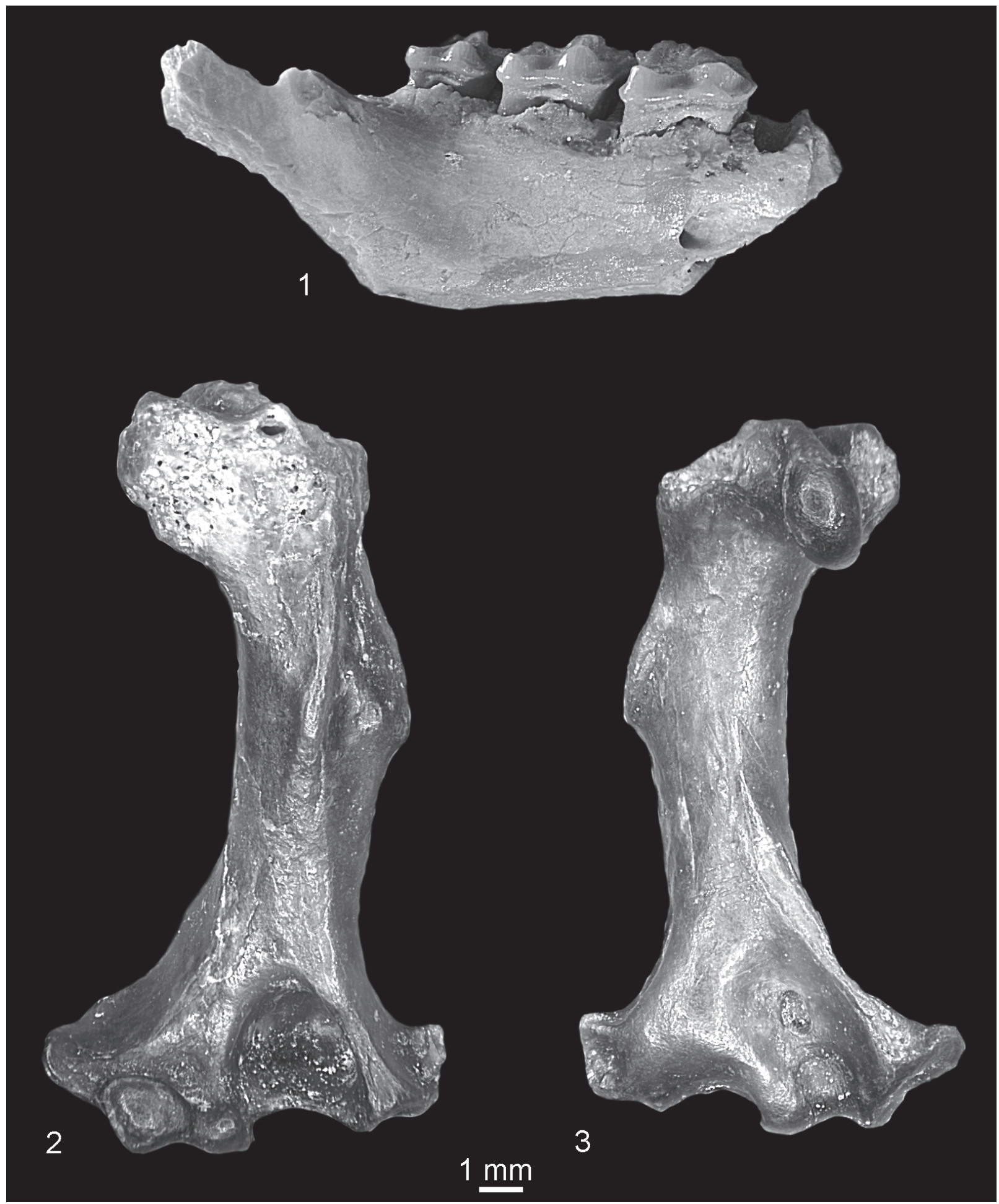

FIGURE 6. 1, Desmana sp. from Popovo 1 (1). fragment of right mandible with m1-m3 in buccal view (c.n. 29/l/4/2); (2-3 ) cf. Desmana sp. from Verkhnya Krynitsa 2, left humerus, 2, dorsal side, 3, ventral side (c.n. 29/2/5/1). 
from before MN14). Indeed, Rekovets and Pashkov (2009) listed $D$. cf. verestchagini in Verkhnya Krynitsa 2 and Nesin (2013) D. cf. nehringi and $D$. (Archaeodesmana) sp. in Odessa, sixteenth Station of Bolshoy Fontan and Vinogradovka 1 (MN13) but they did not give any documentary evidence. Moreover the humerus described above is too large to represent $D$. verestchagini and $D$. nehringi. If this specimen really comes from this locality (Verkhnya Krynitsa 2) (we should take into consideration that it could come from a younger layer in the same locality or from another, younger locality) it would be the oldest record of the genus Desmana and move its first appearance to the Miocene. More material is needed to clarify this problem.

Family SORICIDAE Fischer, 1814

Subfamily CROCIDOSORICINAE Reumer, 1987

Genus MIOSOREX Kretzoi, 1959

cf. Miosorex sp.

Figure 7.1

Material. Verkhnya Krynitsa 2 (MN11/MN12), right I1. $\mathrm{MNI}=1$. Catalogue number 29/2/6.

Description. The I1 (Figure 7.1) is not fissident. Its upper margin is extremely convex and the apex curved down. The ventral edge of the apex is straight with a small denticle situated near the talon. There is an acute angle between the apex and the talon. The talon is slightly bulbous on the buccal side. The posterior cingulum is wide.

Measurements. See Table 5.

Systematic Position. The 11 from Verkhnya Krynitsa 2 is different from I1 of all known soricid species with the exception of this tooth in the subfamily Crocidosoricinae and especially in the genus Miosorex. Unfortunately, it is relatively large, larger than I1 of any form of that subfamily, even of the largest Miosorex, a genus with the longest stratigraphic range. However, according to de Jong (1988), M. grivensis enlarged its dimensions with geological age. The youngest remains of Miosorex are known so far from MN10 (France, Farjanel and Mein, 1984; Spain, van den Hoek Ostende and Furió, 2005) and the described $I 1$ is dated to MN11/MN12. It is, therefore, much younger than French and Spanish specimens, and perhaps this explains its larger size. If the identification is correct, it is the youngest and the largest Miosorex species known so far, and it enlarges the geographical range of the species eastward.

\section{Miosorex grivensis (Depéret, 1892)}

Figure 7.2
Material. Popovo 3 (MN11), right fragment of mandible with $\mathrm{m} 2$ and paraconid and protoconid of $\mathrm{m} 3$. $\mathrm{MNI}=1$. Catalogue number $29 / \mathrm{III} / 7$.

Description. The $\mathrm{m} 2$ (Figure 7.2) has a trigonid and talonid similar in size. The protoconid is the highest cusp, the entoconid crest is high and the entostylid is present. The buccal re-entrant valley opens at some distance above the buccal cingulid. The tooth is surrounded by a broad cingulid, and the anterior cingulid is well pronounced.

Measurements. See Table 5.

Systematic Position and Distribution. The size of $\mathrm{m} 2$ from Popovo 3 corresponds with the $\mathrm{m} 2$ of Miosorex aff. grivensis (Depéret, 1892) from the Middle Miocene (MN9) Spanish locality Pedregueras 2A (de Jong, 1988) which was cited later by van den Hoek Ostende and Furió (2005) as M. grivensis. According to de Jong's (1988) description, specimens from Pedregueras $2 \mathrm{~A}$ are characterized by low entoconid crests and the lack of lingual cingulids in lower molars while the $\mathrm{m} 2$ from Popovo 3 has a rather high entoconid crest and lingual cingulid present. However, Figure 7 (plate 5, de Jong, 1988) shows the lingual side of Miosorex aff. grivensis m1-m3 where high entoconid crests and clear lingual cingulids are visible. In this situation the identical mandible from Popovo 3 is classified as $M$. grivensis. The species was described in France at locality La Grive dated to MN7+8. During the Miocene (MN4-MN10) it was extremely common in the Iberian Peninsula (van den Hoek Ostende and Furió, 2005; Furió et al., 2011). It was also found in Germany (MN4-MN7+8) and in Hungary (MN9) neighboring to Ukraine (Mészáros, 2000; Ziegler et al., 2005).

Subfamily SORICINAE Fischer, 1814

Tribe ANOUROSORICINI Anderson, 1879

Genus CRUSAFONTINA Gibert, 1974

Crusafontina cf. kormosi (Bachmayer and Wilson, 1970)

Figure 8.1-8.5

Material. Verkhnya Krynitsa 2 (MN11/MN12), left fragment of mandible with i1 - p4, left fragment of mandible with $\mathrm{m} 2-\mathrm{m} 3$ and coronoid and condyloid processes, left fragment of mandible with $\mathrm{m} 1-\mathrm{m} 2$ without processes, right fragment (talonid) of $\mathrm{m} 2$ and right fragment of mandible without teeth and processes. $\mathrm{MNI}=2$. Catalogue number 29/2/8.

Description. All teeth are massive. The i1 (Figure 8.1 ) is slightly damaged in its cutting edge and its number of cusps (two or three) is unknown. Its apex is bent upward and a buccal cingulid is lacking. The a1 and the p4 (Figure 8.1) are unicuspid. The postero-lingual basin of a1 is almost absent, 


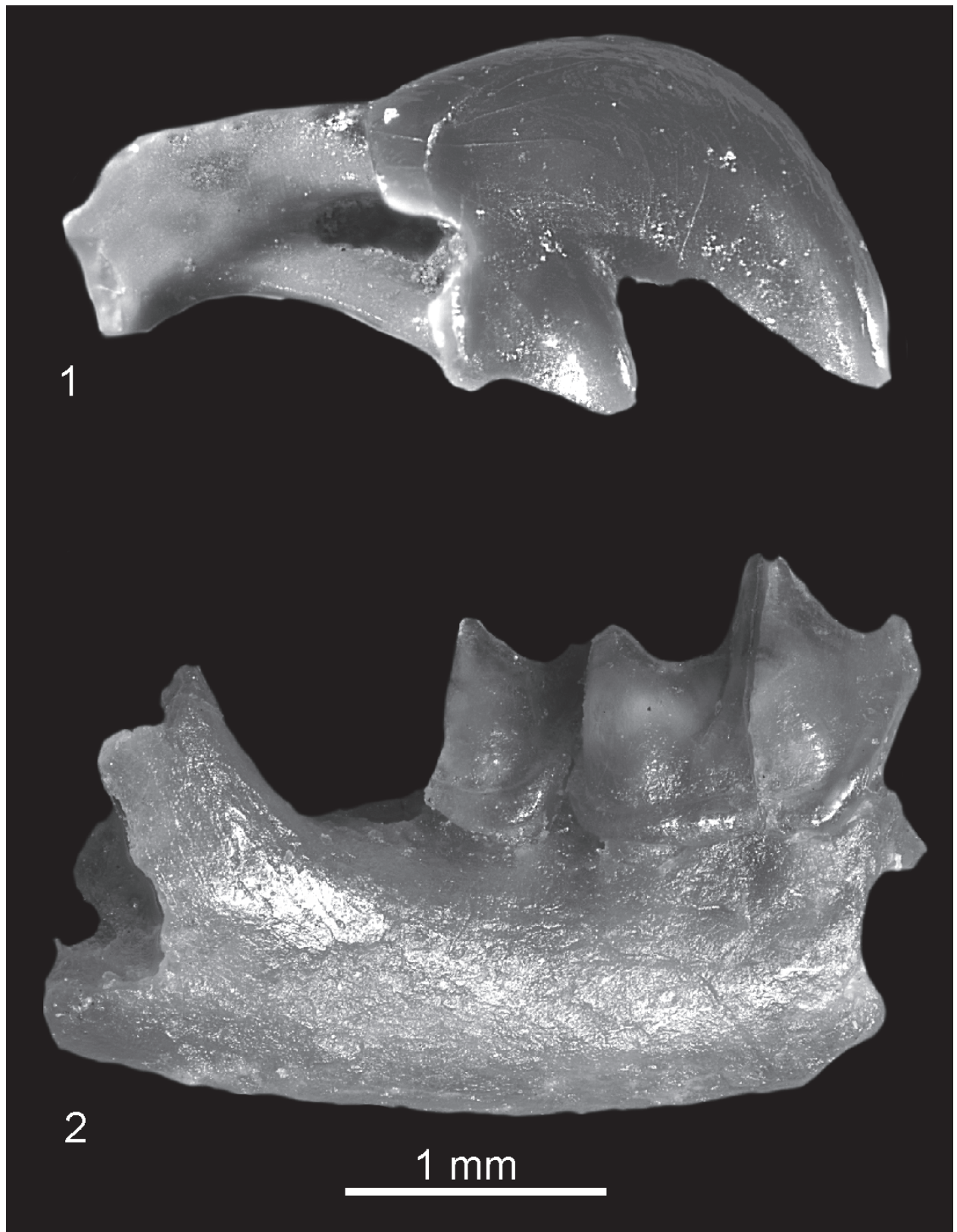

FIGURE 7. 1, cf. Miosorex sp. from Verkhnya Krynitsa 2, right I1, buccal view (c.n. 29/2/6/1). 2, Miosorex grivensis from Popovo 3, fragment of right mandible with $\mathrm{m} 2$ and trigonid of $\mathrm{m} 3$, buccal view (c.n. 29/III/7/1).

that of p4 is small and very shallow. The buccal and lingual cingulids of both teeth are wide, and they do not reach their anterior apexes. The $\mathrm{m} 1$ (Figure 8.2) has bulbous cusps and an elongated trigonid. Its re-entrant valley is shallow, its entoconid and entostylid are separated by a groove, the anterior, buccal and posterior cingulids are not very wide, and the lingual cingulid is absent. The buccal cingulid is very wavy. The $\mathrm{m} 2$ (Figures 8.2, 8.4-5) is similar but smaller. The $\mathrm{m} 3$ (Figure 8.3 ) is very small and its talonid is reduced. It is surrounded by a continuous crest.

The horizontal ramus of the mandible is slightly concave under the $\mathrm{m} 1 / \mathrm{m} 2$ junction. The coronoid process is large. Its coronoid spicule is distinct and situated high. The external temporal fossa is deep but not very long. It extends to the level of the upper sigmoid notch. The internal temporal fossa is high and divided by a horizontal bar separating the deep lower part from the shallow higher part of the fossa. The condyloid process is 
TABLE 5. Dimensions (in $\mathrm{mm}$ ) of mandible and upper and lower teeth of Miosorex species.

\begin{tabular}{|c|c|c|c|c|c|}
\hline & & $\begin{array}{c}\text { Miosorex grivensis } \\
\text { Popovo } 3 \\
\text { Ukraine } \\
\text { MN11 }\end{array}$ & $\begin{array}{c}\text { cf. Miosorex sp. } \\
\text { Verkhnyaya Krinitsa } 2 \\
\text { Ukraine } \\
\text { MN11/MN12 }\end{array}$ & $\begin{array}{c}\text { Miosorex grivensis } \\
\text { Pedregueras 2A } \\
\text { Spain } \\
\text { (MN9) } \\
\text { De Jong 1988, van den } \\
\text { Hoek Ostende and Furió } \\
2005\end{array}$ & $\begin{array}{c}\text { Miosorex aff. grivensis } \\
\text { Petersbuch } 10 \text { and } 31^{a} \\
\text { Germany } \\
\text { MN7+8 } \\
\text { Ziegler } 2003\end{array}$ \\
\hline \multirow[t]{3}{*}{11} & $L$ & - & 2.02 & - & - \\
\hline & $\mathrm{L}$ of talon & - & 1.08 & - & 0.68 \\
\hline & W & - & 1.35 & - & 1.16 \\
\hline \multirow[t]{2}{*}{$\mathrm{m} 2$} & L & 1.30 & - & $1.27-1.57, n=7$ & $1.37-150, n=25^{a}$ \\
\hline & W & 0.84 & - & $0.88-1.01, n=7$ & $0.80-0.91, n=25^{a}$ \\
\hline $\mathrm{H}$ of $\mathrm{m}$ & $\begin{array}{l}\text { ndible below } \\
\text { m2 }\end{array}$ & 1.29 & - & - & - \\
\hline
\end{tabular}

high, its interarticular area is narrow and the lower facet elongated and concave. The mental foramen is situated below the anterior root of $\mathrm{m} 1$, slightly forward in relation to its protoconid. One mandibular foramen is situated below the anterior part of the internal temporal fossa (Figure 8.3).

Measurements. See Table 6.

Systematic Position and Distribution. The teeth are not very bulbous, the presence of the $\mathrm{m} 3$ and serration of the $\mathrm{i} 1$ indicate that these Anourosoricini specimens belong to the genus Crusafontina Gibert, 1974 (Mészáros, 1998; van Dam, 2004). Recently, six valid species have been included in this genus (see Rzebik-Kowalska and Lungu, 2009; Rzebik-Kowalska and Nesin, 2010). They lived in Europe in the Middle and Late Miocene. The size of remains from Verkhnya Krynitsa 2 lie in the range of variation of the size of two European species, C. endemica Gibert, 1974 and especially C. kormosi (Bachmayer and Wilson, 1970).

Crusafontina fastigata van Dam, 2004 known from Spain, and probably similar in size, cannot be directly compared with Ukrainian specimens because it was described on the basis of the upper teeth. C. endemica and C. kormosi are very similar in morphology, the latter differs only by a slightly more posterior position of the mental foramen situated between the roots of $\mathrm{m} 1$ (in $C$. endemica it is situated below the trigonid of $\mathrm{m} 1$ ), a slightly deeper re-entrant valley in $\mathrm{m} 1$ and a different ratio of the length of $\mathrm{m} 2 / \mathrm{m} 1$ and $\mathrm{m} 3 / \mathrm{m} 1$ (van Dam, 2004; Ziegler, 2006). In C. kormosi the $\mathrm{m} 2$ and $\mathrm{m} 3$ are more reduced than in $C$. endemica and its $\mathrm{m} 2 / \mathrm{m} 1$ ratio is below 0.70 (about 0.80 in $C$. endemica) and its $\mathrm{m} 3 / \mathrm{m} 1$ ratio is below 0.40 (it exceeds this value in $C$. endemica). In the studied specimens the $\mathrm{m} 2 / \mathrm{m} 1$ ratio is 0.68 and $\mathrm{m} 3 / \mathrm{m} 1$ ratio is ?0.38 ( $\mathrm{m} 1$ and $\mathrm{m} 3$ are isolated and may belong to two dif- ferent specimens). These ratios as well as the rather deep re-entrant valley in the lower $\mathrm{m} 1$ and $\mathrm{m} 2$ indicate that the mandibles described here belong to $C$. kormosi. However, the mental foramen present in one of the specimens is situated below the anterior root of $\mathrm{m} 1$ as in $C$. endemica. Having in mind the reduction of teeth, larger size and possibly the age of specimens (MN11/MN12), they have been tentatively ascribed to $C$. cf. kormosi. Its youngest (MN13) remains are known from Polgárdi 4 (Hungary; Mészáros, 1998) while $C$. endemica has not been recorded later than MN11.

The species is already known from older Ukrainian localities, Mikhailovka 1 (MN10) and Frunzovka 2 (MN11) (Rzebik-Kowalska and Nesin, 2010).

Tribe NEOMYINI Matschie, 1909

Genus ASORICULUS Kretzoi, 1959

cf. Asoriculus sp.

Figure 9.1-9.2

Material. Popovo 3 (MN11), two right fragments of mandibles, one with coronoid and condyloid processes, the second with $\mathrm{m} 2-\mathrm{m} 3$, without processes. $\mathrm{MNI}=2$. Catalogue number 29/ III/9. Verkhnya Krynitsa 2 (MN11/MN12), right fragment of mandible with $\mathrm{m} 1$ (damaged on the buccal side), fragment of $\mathrm{m} 2$ and fragment of $\mathrm{m} 3 . \mathrm{MNI}=1$. Catalogue number 29/2/9.

Description. The $\mathrm{m} 2$ (Figure 9.2) has a wider talonid than the trigonid, its entoconid crest is fairly high, the lingual lower margin slightly convex (navicular), the buccal re-entrant valley opens directly above the cingulid and cingulids are distinct, the anterior and buccal are wider and more protruding than the lingual and posterior ones. The $\mathrm{m} 3$ (Figure 9.2) is relatively large. Its talonid is unreduced, elongated and basined, possessing a trace of the hypoconid and entoconid. The anterior 


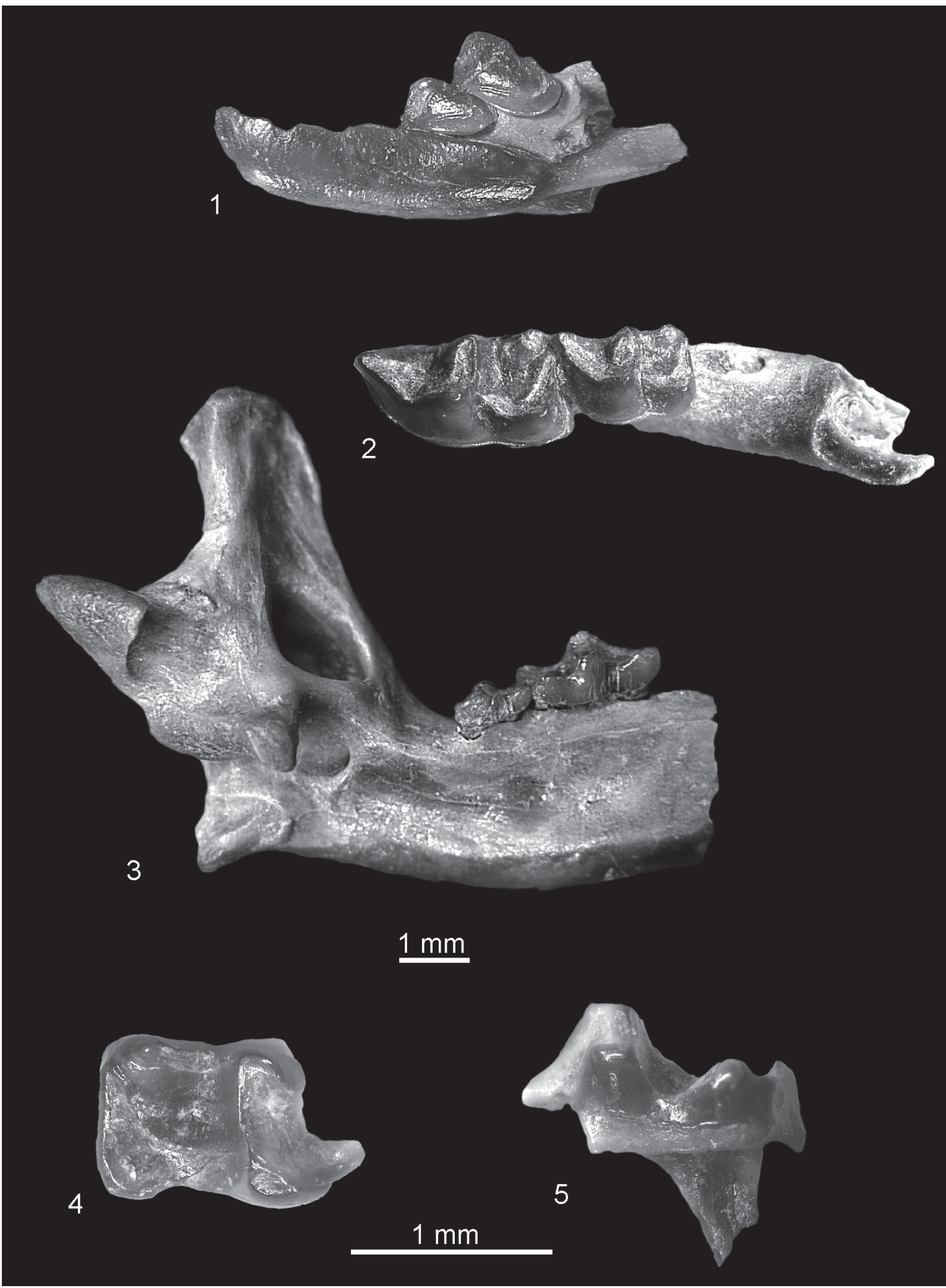

FIGURE 8. Crusafontina cf. kormosi from Verkhnya Krynitsa 2. 1, fragment of left mandible with i1-p4 in buccal view (c.n. 29/2/8/1); 2, fragment of left mandible with m1-m2 in occlusal view (c.n. 29/2/8/2); 3, fragment of left mandible with m2-m3 and coronoid and condyloid proceses in lingual view (c.n. 29/2/8/3). (4-5), Fragment (talonid) of right m2 in: 4, occlusal; and 5, lingual view (c.n. 29/2/8/5). 
TABLE 6. Dimensions (in $\mathrm{mm}$ ) of mandible and lower teeth of Crusafontina.

\begin{tabular}{|c|c|c|c|c|c|c|}
\hline & & $\begin{array}{l}\text { Crusafontina } \\
\text { cf. kormosi } \\
\text { Verkhnyaya } \\
\text { Krinitsa } 2 \\
\text { Ukraine } \\
\text { MN11/MN12 }\end{array}$ & $\begin{array}{c}\begin{array}{c}\text { Crusafontina } \\
\text { kormosi }\end{array} \\
\text { Mikhailovka } 1 \\
\text { Ukraine } \\
\text { MN10 } \\
\text { Rzebik-Kowalska } \\
\text { and Nesin } 2010\end{array}$ & $\begin{array}{c}\text { Crusafontina } \\
\text { kormosi } \\
\text { Frunzovka } 2 \\
\text { Ukraine } \\
\text { MN11 } \\
\text { Rzebik-Kowalska } \\
\text { and Nesin } 2010\end{array}$ & $\begin{array}{c}\text { Crusafontina endemica } \\
10-13 \text { localities } \\
\text { Spain, France, Hungary } \\
\text { MN9-MN10 } \\
\text { Gibert 1975, Crochet } \\
\text { and Green 1982, } \\
\text { De Jong 1988, } \\
\text { Mészáros 1998, Van } \\
\text { Dam 2004 }\end{array}$ & $\begin{array}{c}\text { Crusafontina kormosi } \\
5 \text { localities } \\
\text { Austria, Hungary, } \\
\text { Germany } \\
\text { MN10-MN13 } \\
\text { Bachmayer and Wilson } \\
\text { 1970, Mészáros 1998, } \\
\text { Ziegler } 2006\end{array}$ \\
\hline \multirow[t]{2}{*}{ i1 } & $L$ & 5.04 & 5.90 & - & $4.40-5.12, n=4$ & $4.25-5.56, n=18$ \\
\hline & W & 1.37 & 1.53 & - & $1.04-1.19, n=4$ & $1.06-1.52, n=18$ \\
\hline \multirow[t]{2}{*}{$\mathrm{p} 4$} & L & 1.70 & 1.81 & 1.62 & $1.15-1.61, n=11$ & $1.35-1.61, n=10$ \\
\hline & W & 1.20 & 1.58 & 1.17 & $0.91-1.08, n=11$ & $1.12-1.25, n=10$ \\
\hline \multirow[t]{2}{*}{$\mathrm{m} 1$} & L & 2.90 & - & $2.37-2.63, n=8$ & $1.90-2.72, n=36$ & $2.38-3.20, n=147$ \\
\hline & W & 1.61 & - & $1.34-1.47, n=8$ & $1.02-1.52, n=36$ & $1.16-1.64, n=147$ \\
\hline \multirow[t]{2}{*}{$\mathrm{m} 2$} & L & $1.90-1.96$ & - & $1.62-1.77, n=6$ & $1.54-1.90, n=20$ & $1.20-2.28, n=121$ \\
\hline & W & $1.20-1.38$ & - & $1.00-1.19, n=6$ & $0.80-1.15, n=20$ & $0.88-1.66, n=116$ \\
\hline \multirow[t]{2}{*}{$\mathrm{m} 3$} & L & 1.11 & - & 0.97 & $0.88-1.25, n=21$ & $0.55-1.34, n=58$ \\
\hline & W & 0.81 & - & 0.71 & $0.30-0.98, n=21$ & $0.30-0.84, n=58$ \\
\hline \multicolumn{2}{|c|}{$\begin{array}{l}\mathrm{H} \text { of mandible } \\
\text { below } \mathrm{m} 2\end{array}$} & $2.48-2.58$ & - & $2.08-2.47, n=6$ & - & - \\
\hline \multicolumn{2}{|c|}{$\begin{array}{l}\mathrm{H} \text { of ascending } \\
\text { ramus }\end{array}$} & 6.52 & - & $6.33-6.63, n=3$ & - & $5.71-6.58, n=52$ \\
\hline \multicolumn{2}{|c|}{$\begin{array}{l}\text { W of coronoid } \\
\text { process }\end{array}$} & 1.91 & - & $1.50-1.90, n=5$ & - & - \\
\hline \multicolumn{2}{|c|}{$\begin{array}{l}\mathrm{H} \text { of condyloid } \\
\text { process }\end{array}$} & 3.47 & - & $3.27-3.73, n=4$ & - & - \\
\hline \multicolumn{2}{|c|}{$\begin{array}{l}\text { W of interarticular } \\
\text { area }\end{array}$} & 0.61 & - & $0.27-0.39, n=5$ & - & - \\
\hline
\end{tabular}

margin of the mandible is rather straight and its posterior margin is concave. The coronoid spicule is well developed and placed low, i.e., about halfway between the tip of the coronoid process and the upper sigmoid notch. The external temporal fossa is shallow, and it reaches halfway down the condyloid process (Figure 9.1). The internal temporal fossa is relatively small, and it continues upwards as a shallow groove. The upper and lower facets of the condyle are damaged and the interarticular area is narrow. Two mandibular foramina are present (catalogue number 29/III/9/1).

Measurements. See Table 7.

Systematic Position and Distribution. The size and characters of the remains and especially the low position of the coronoid spicule and narrow interarticular area of the condyloid process opted for their ascription to the tribe Neomyini and the genus Asoriculus. However, some differences between the typical Asoriculus and specimens from Ukraine are visible. These include a rather high entoconid crest in $\mathrm{m} 2$ (slightly higher than general in Asoriculus species), two mandibular foramina (instead of one) and the anterior margin of the coronoid process rather straight (instead of concave). As the available material is very poor and damaged, its precise identification is impossible especially since individual variation of particular characters of the rare Miocene forms is unknown. Similar old and poor material (one fragment of mandible) was already mentioned from Frunzovka 2 (MN10) in Ukraine and one upper incisor I1 from neighboring Kejnar, MN10, in Republic of Moldova (Rzebik-Kowalska and Lungu 2009). Other specimens yielded younger localities dated to MN13 (e.g., Maramena in Greece, Doukas et al., 1995). On the other hand, the genus was widely distributed in Europe (from Spain to Bulgaria and Greece; van den Hoek Ostende et al., 2005; Rzebik-Kowalska, 2009) throughout the Pliocene and the Early Pleistocene. It survived until the end of the Early Pleistocene. It was also excavated in Asia Minor (Storch et al., 1998; Early Pliocene) and in North Africa (Morocco; Rzebik-Kowalska, 1988; Stoetzel, 2013; Pliocene/Pleistocene boundary).

Genus NEOMYSOREX Rzebik-Kowalska, 1981 Neomysorex alpinoides (Kowalski, 1956)

Figure 9.3 


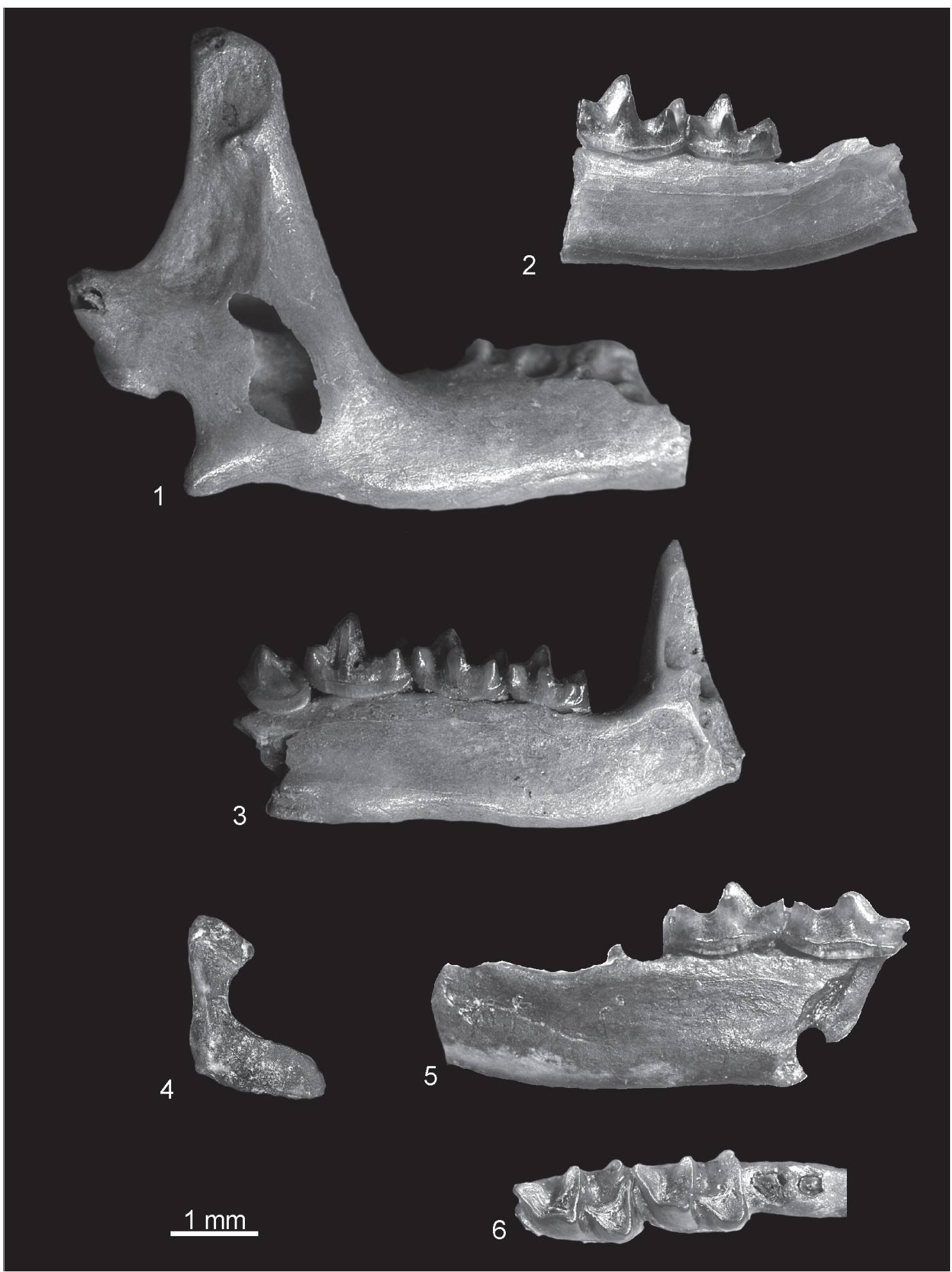

FIGURE 9. (1-2) cf. Asoriculus sp. from Popovo 3: 1, fragment of right mandible with coronoid process, buccal view (c.n. 29/III/9/1). 2, fragment of right mandible with m2-m3, lingual view (c.n. 29/III/9/2). (3) Neomysorex alpinoides from Verkhnya Krynitsa 2, fragment of right mandible with p4-m3, lingual view (c.n. 29/2/10/1), (4-6) Neomys newtoni from Medzhybozh: 4, left condyloid process, posterior view (c.n. 29/4/11/2); fragment of left mandible with m1-m2, in 5, lingual, and 6, occlusal view (c.n. 29/4/11/1). 
TABLE 7. Dimensions (in $\mathrm{mm}$ ) of mandible and lower teeth of Asoriculus species ( ${ }^{*}$ specimen a little damaged).

\begin{tabular}{|c|c|c|c|c|c|c|c|c|}
\hline & & $\begin{array}{l}\text { cf. Asoriculus sp. } \\
\text { Popovo } 3 \\
\text { Ukraine } \\
\text { MN11 }\end{array}$ & $\begin{array}{c}\text { Asoriculus } \\
\text { sp. } \\
\text { Frunzovka } 2 \\
\text { Ukraine } \\
\text { MN11 } \\
\text { Rzebik- } \\
\text { Kowalska and } \\
\text { Nesin } 2010\end{array}$ & $\begin{array}{c}\text { cf. Asoriculus } \\
\text { sp. } \\
\text { Verkhnyaya } \\
\text { Krinitsa 2 } \\
\text { Ukraine } \\
\text { MN11/MN12 }\end{array}$ & $\begin{array}{c}\text { Asoriculus cf. } \\
\text { gibberodon } \\
\text { Odessa } \\
\text { Ukraine } \\
\text { MN13 } \\
\text { Rzebik- } \\
\text { Kowalska and } \\
\text { Nesin } 2010\end{array}$ & $\begin{array}{c}\text { Asoriculus } \\
\text { gibberodon } \\
\text { Maramena } \\
\text { Greece } \\
\text { MN13 } \\
\text { Doukas et al. } \\
1995\end{array}$ & $\begin{array}{c}\text { Asoriculus } \\
\text { gibberodon } \\
\text { Osztramos } 1 \text { and } 9 \\
\text { Hungary } \\
\text { MN14 } \\
\text { Reumer } 1984\end{array}$ & $\begin{array}{c}\text { Asoriculus } \\
\text { gibberodon } \\
\text { Podlesice } \\
\text { Poland } \\
\text { MN14 } \\
\text { Rzebik-Kowalska } \\
1981\end{array}$ \\
\hline \multirow[t]{2}{*}{$\mathrm{m} 1$} & $\mathrm{~L}$ & - & - & 1.45 & - & $1.31-1.56, n=14$ & $1.38-1.58, n=17$ & $1.50-1.62, n=13$ \\
\hline & W & - & - & $0.82^{*}$ & - & $0.73-0.93, n=16$ & $0.77-0.94, n=20$ & $0.78-0.90, n=13$ \\
\hline \multirow[t]{2}{*}{$\mathrm{m} 2$} & L & 1.31 & - & - & - & $1.23-1.46, n=19$ & $1.27-1.56, n=19$ & $1.30-1.46, n=13$ \\
\hline & W & 0.83 & - & - & - & $0.72-0.86, n=20$ & $0.65-0.79, n=20$ & $0.69-0.82, n=12$ \\
\hline \multirow[t]{2}{*}{ m3 } & L & 1.11 & - & - & - & $0.97-1.11, n=9$ & $1.00-1.15, n=10$ & $1.01-1.09, n=8$ \\
\hline & W & 0.61 & - & - & - & $0.55-0.59, n=9$ & $0.52-0.68, n=10$ & $0.55-0.59, n=8$ \\
\hline \multicolumn{2}{|c|}{$\begin{array}{l}\mathrm{H} \text { of mandible } \\
\text { below } \mathrm{m} 2\end{array}$} & $1.33-1.45, n=2$ & - & $1.28^{*}$ & 1.38 & - & - & $1.22-1.42, n=13$ \\
\hline \multicolumn{2}{|c|}{$\begin{array}{l}\mathrm{H} \text { of ascending } \\
\text { ramus }\end{array}$} & 4.46 & 5.83 & - & 3.80 & - & $3.92-4.23, n=4$ & $3.82-4.01, n=2$ \\
\hline \multicolumn{2}{|c|}{$\begin{array}{l}\text { W of coronoid } \\
\text { process }\end{array}$} & 0.89 & 1.40 & - & 0.61 & - & - & - \\
\hline \multicolumn{2}{|c|}{$\begin{array}{l}\text { W of } \\
\text { interarticular } \\
\text { area }\end{array}$} & 0.30 & 0.35 & - & 0.40 & - & - & $0.38-0.50, n=4$ \\
\hline
\end{tabular}

Material. Verkhnya Krynitsa 2 (MN11/MN12), two right fragments of mandible with $\mathrm{p} 4-\mathrm{m} 3$, without processes. $\mathrm{MNI}=2$. Catalogue number 29/2/10.

Description. The typically soricine $\mathrm{p} 4$ is doublecusped with the postero-lingual basin and the buccal overhang over the root. Its buccal and lingual cingulids are wide. The lower molars have high entoconid crests, their lingual border shows strong convexity (boat-shaped), and wide cingulids are lingually less developed and protruding than buccally. The talonid of $\mathrm{m} 3$ is unreduced (Figure 9.3).
The mental foramen is placed underneath the reentrant valley of $\mathrm{m} 1$.

Measurements. See Table 8.

Systematic Position and Distribution. The small size and the morphology of the lower molars, especially the navicular shape of their lower lingual border, rare in Soricinae species (present only in very small Paenelimnoecus and larger Hemisorex), as well as the posterior position of the mental foramen suggest their affiliation to Neomysorex. This genus was described from the younger (MN14) locality

TABLE 8. Dimensions (in $\mathrm{mm}$ ) of mandible and lower teeth of Neomysorex species.

\begin{tabular}{|c|c|c|c|c|c|}
\hline & & $\begin{array}{l}\text { ?Neomysorex cf. } \\
\text { alpinoides } \\
\text { Frunzovka } 2 \\
\text { Ukraine } \\
\text { MN11 } \\
\text { Rzebik-Kowalska } \\
\text { and Nesin } 2010\end{array}$ & $\begin{array}{l}\text { ?Neomysorex cf. } \\
\text { alpinoides } \\
\text { Mikhailovka } 2 \\
\text { Ukraine } \\
\text { MN11 } \\
\text { Rzebik-Kowalska } \\
\text { and Nesin } 2010\end{array}$ & $\begin{array}{c}\text { Neomysorex } \\
\text { alpinoides } \\
\text { Verkhnyaya Krinitsa } \\
2 \\
\text { Ukraine } \\
\text { MN11/MN12 }\end{array}$ & $\begin{array}{c}\text { Neomysorex } \\
\text { alpinoides } \\
\text { Podlesice } \\
\text { Poland } \\
\text { MN14 } \\
\text { Rzebik-Kowalska } \\
1981\end{array}$ \\
\hline \multirow[t]{2}{*}{ p4 } & $\mathrm{L}$ & - & - & $1.01 ; 1.05$ & $0.91-1.03, n=7$ \\
\hline & W & - & - & $0.75 ; 0.77$ & $0.62-0.75, n=8$ \\
\hline \multirow[t]{2}{*}{$\mathrm{m} 1$} & $\mathrm{~L}$ & - & - & $1.33 ; 1.49$ & $1.35-1.48, n=15$ \\
\hline & W & - & - & $0.84 ; 0.90$ & $0.75-0.82, n=15$ \\
\hline \multirow[t]{2}{*}{ m2 } & $\mathrm{L}$ & 1.15 & 1.16 & $1.20 ; 1.29$ & $1.17-1.33, n=12$ \\
\hline & W & 0.72 & 0.69 & $0.78 ; 0.80$ & $0.72-0.75, n=12$ \\
\hline \multirow[t]{2}{*}{ m3 } & $\mathrm{L}$ & - & - & $1.01 ; 1.14$ & \\
\hline & W & - & - & $0.60 ; 0.66$ & $0.53-0.60, n=6$ \\
\hline $\mathrm{m} 1-\mathrm{m} 3$ & $\mathrm{~L}$ & - & - & $3.50 ; 3.87$ & $3.44-3.64, n=6$ \\
\hline \multicolumn{2}{|c|}{$\mathrm{H}$ of mandible below $\mathrm{m} 2$} & 1.05 & 1.18 & $1.35 ; 1.41$ & 1.15-1.37, n=15 \\
\hline
\end{tabular}


TABLE 9. Dimensions (in $\mathrm{mm}$ ) of mandible and lower teeth of Neomys newtoni.

\begin{tabular}{|c|c|c|c|c|c|}
\hline & & $\begin{array}{l}\text { Neomys newtoni } \\
\text { Medzhybozh } \\
\text { Ukraine } \\
\text { Q3 }\end{array}$ & $\begin{array}{c}\text { Neomys newtoni } \\
\text { Żabia Cave } \\
\text { Poland } \\
\text { Early Pleistocene } \\
\text { Q1 } \\
\text { Rzebik-Kowalska } \\
2013\end{array}$ & $\begin{array}{c}\text { Neomys newtoni } \\
\text { Kozi Grzbiet } \\
\text { Poland } \\
\text { Early/Middle } \\
\text { Pleistocene } \\
\text { Q2/Q3 } \\
\text { Rzebik-Kowalska } \\
1991\end{array}$ & $\begin{array}{c}\text { Neomys newtoni } \\
\text { Treugolnaya Cave } \\
\text { Russia } \\
\text { Middle Pleistocene } \\
\text { Zaitsev and } \\
\text { Baryshnikov } 2002\end{array}$ \\
\hline \multirow[t]{2}{*}{$\mathrm{m} 1$} & $\mathrm{~L}$ & 1.62 & - & $1.65-1.71, n=2$ & 1.60 \\
\hline & W & 0.99 & - & $0.91-1.06, n=2$ & - \\
\hline \multirow[t]{2}{*}{$\mathrm{m} 2$} & $\mathrm{~L}$ & 1.51 & - & 1.54 & - \\
\hline & W & 0.92 & - & 0.99 & - \\
\hline \multicolumn{2}{|c|}{$\mathrm{H}$ of mandible below $\mathrm{m} 2$} & 1.47 & - & $1.45-1.49, n=2$ & 1.40 \\
\hline \multicolumn{2}{|c|}{$\mathrm{H}$ of condyloid process } & 2.18 & $2.11-220, n=2$ & 2.03 & 2.15 \\
\hline \multicolumn{2}{|c|}{ W of interarticular area } & 0.42 & $0.47-0.48, n=2$ & $0.28-0.42, n=2$ & 0.35 \\
\hline
\end{tabular}

Podlesice in Poland (Rzebik-Kowalska, 1981) and was also listed from another Polish locality Zalesiaki 1B (MN14/15?; Rzebik-Kowalska, 1994).

It was previously found in older (MN11) Ukrainian localities Frunzovka 2 and Mikhailovka 2 (Rzebik-Kowalska and Nesin, 2010) and also mentioned by Nesin and Nadachowski (2001) from the Late Ruscinian (beginning of MN15).

Genus NEOMYS Kaup, 1829

Neomys newtoni Hinton, 1911

Figure 9.4-9.6

Material. Medzhybozh (early Middle Pleistocene, Q3), two left fragments of mandible, one with m1$\mathrm{m} 2$ and one with coronoid and condyloid processes. MNI=1. Catalogue number 29/4/11.

Description. The $\mathrm{m} 1$ (Figure 9.5-6) is rather massive (in relation to $\mathrm{m} 1$ of other small Neomys species). Its talonid is wider than the trigonid, the entoconid and the hypolophid are separated by a groove, the entoconid crest is high and the cingulids are wide (the lingual cingulid is less protruding than the buccal one). The $\mathrm{m} 2$ (Figure 9.5-6) is similar to $\mathrm{m} 1$ but smaller. The coronoid process is low and its tip is slightly damaged. The upper facet of the condyle is small, the lower is wide on the buccal side and narrow on the lingual side. The interarticular area is very narrow in the middle and it widens towards the upper and lower facets (Figure 9.4).

Measurements. See Table 9.

Systematic Position and Distribution. The morphology of the teeth and the condyloid process indicate that the remains described above belong to the tribe Neomyini, the genus Neomys Kaup, 1829 and the species N. newtoni Hinton, 1911. They differ from typical N. browni Hinton, 1911 (Grays Thurrock, England, Late Pleistocene) by being smaller, from similar in size Recent $N$. anomalus Cabrera, 1907 by having a stronger teeth and straight (not buccaly bent) tip of the coronoid process and from the Middle Pleistocene $N$. hintoni described by Zaitsev and Baryshnikov (2002) from the Caucasus by different morphology of its ascending ramus (lack of a deep fossa situated on the buccal side of the ascending ramus). The German species, Neomys intermedius Brunner, 1952 cited from Middle to Late Pleistocene localities of Europe is not taken into consideration because its validity was questioned by several authors, e.g., by Jammot (1977).

Neomys newtoni is known from many Early and Middle Pleistocene localities of several countries of Europe but its remains are always scarce in the fossil material. This is the first record of $N$. newtoni in the Ukraine.

\section{Tribe BEREMENDIINI Reumer, 1984 \\ Genus BEREMENDIA Kormos, 1934 \\ Beremendia fissidens (Pétenyi, 1864) \\ Figure 10.1}

Material. Popovo 2 (late MN16), right I1 slightly damaged on its posterior side (on the crown/root boundary). $\mathrm{MNI}=1$. Catalogue number 29/II/12. Popovo 1 (MN16/MN17), right $\mathrm{m1}$. MNI = 1. Catalogue number 29///12. Popovo 0 (MN17), upper fragment of left coronoid process. $\mathrm{MNI}=1$. Catalogue number 29/0/12.

Description. The 11 (Figure 10.1) is large and strongly fissident. The $\mathrm{m} 1$ is also large. Its trigonid basin is wide and deep, its talonid is wider than the trigonid and its entoconid crest is moderately high. The anterior, buccal and posterior cingulids are very well developed, and the lingual one is less protruding. The tip of the coronoid process is narrow and bends buccally. 


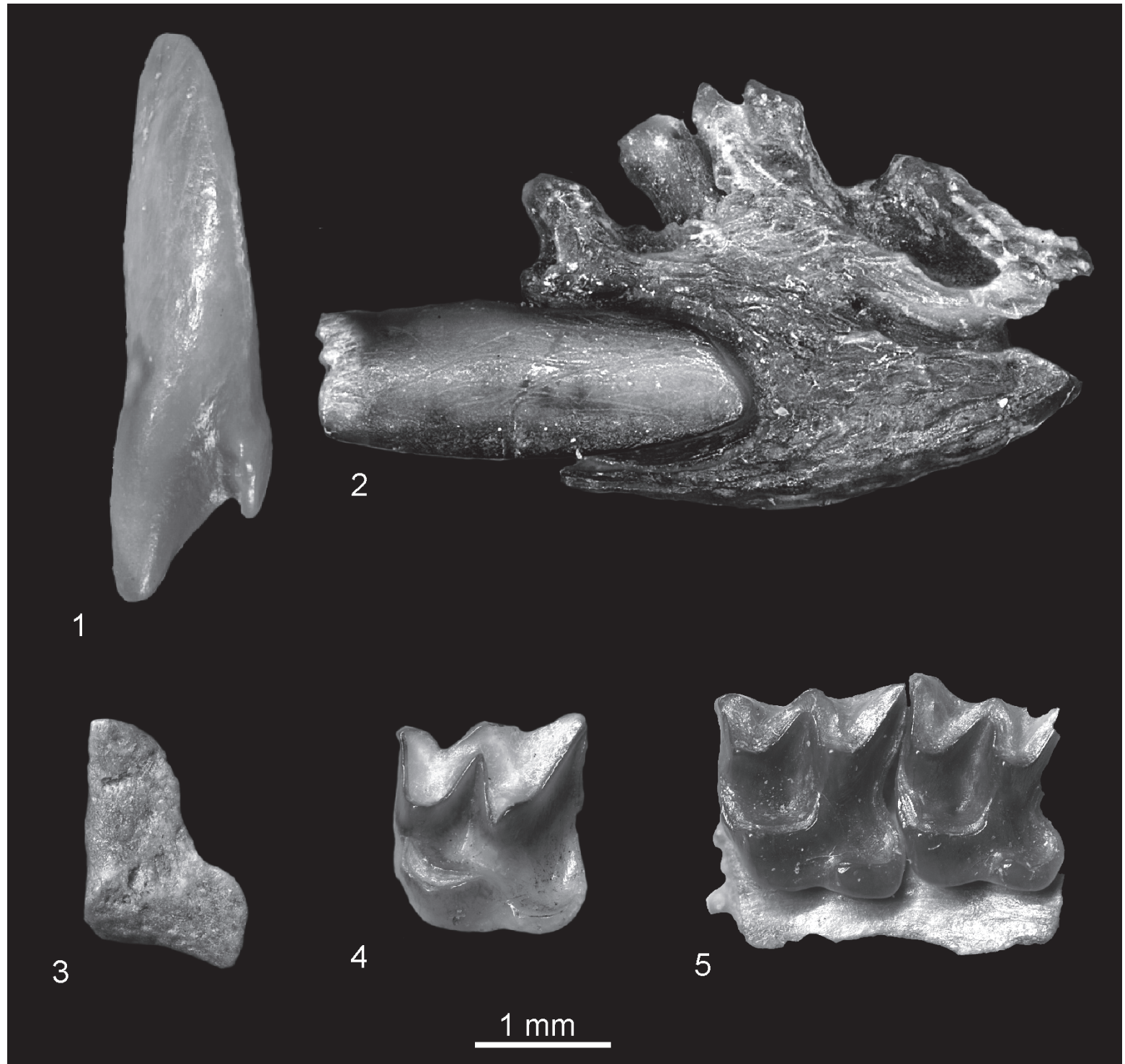

FIGURE 10. 1, Beremendia fissidens from Popovo 1, right I1, in anterior view (c.n. 29/I/12/1); 2, cf. Beremendia minor from Verkhnya Krynitsa 1, fragment of left mandible with proximal part of i1 in buccal view (c.n. 29/1/13/1); Petenyia dubia from Verkhnya Krynitsa 2 (3) and Lobkove (4): 3, left condyloid process, posterior view (c.n. 29/2/14/1); 4, left M1, occlusal view (c.n. 29/3/14/1). 5, Zelceina sp. from Verkhnya Krynitsa 2, fragment of left maxillae with M1-M2, occlusal view (c.n. 29/2/16/1).

Measurements. See Table 10

Systematic Position and Distribution. The morphology of teeth and especially the strongly fissident $I 1$ indicates that the specimens are typical of the genus Beremendia and their large size points to $B$. fissidens. Since the beginning of the Late Ruscinian (MN15) this great opportunist among shrews was ubiquitous in Europe (Rzebik-Kowalska, 1998).

The oldest locality (Zamkowa Dolna Cave B) with remains of Beremendia fissidens is from
Poland and is dated to the Early Pliocene (?MN14). In the Middle Pleistocene it became rare but was still present in southern Europe (Rzebik-Kowalska, 2009).

It is also known in Asia from South Caucasus (Furió et al., 2010) to western Siberia and Transbaikalia (Storch et al., 1998).

\section{cf. B. minor Rzebik-Kowalska, 1976}

Figure 10.2

Material. Verkhnya Krynitsa 1 (early MN16), fragment of left mandible with proximal part of i1, ante- 
TABLE 10. Dimensions (in $\mathrm{mm}$ ) of mandible and upper and lower teeth of Beremendia species.

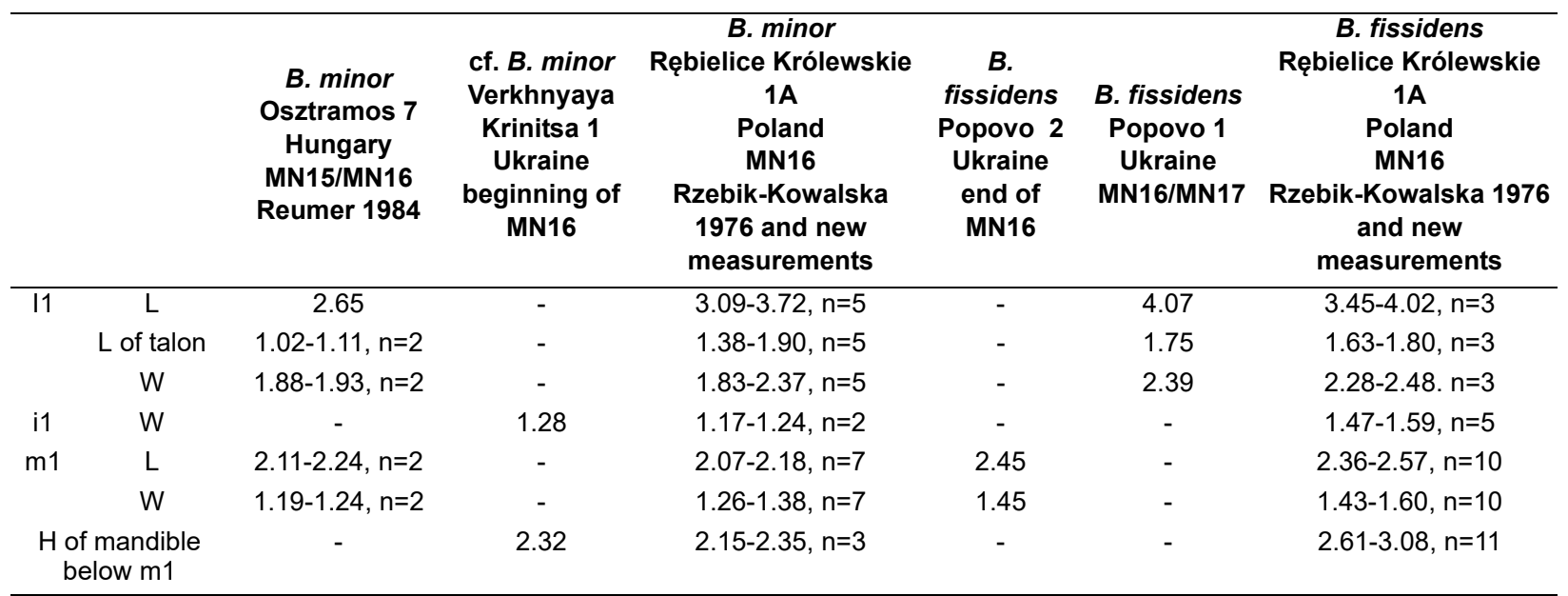

rior root of $\mathrm{m} 1$ and alveolae of $\mathrm{a} 1, \mathrm{p} 4$ and $\mathrm{m} 1 . \mathrm{MNI}$ =1. Catalogue number 29/1/13.

Description. The anterior fragment of the mandible is massive and convex under $\mathrm{m} 1$. The mental foramen damaged at the back and is situated under the second root of $\mathrm{m} 1$. The i1 is devoid of a cingulid.

Measurements. See Table 10.

Systematic Position and Distribution. The anterior part of the mandible with a fragment of i1 (Figure 10.2) is large. Its size is intermediate between the size of such large forms as Mafia dehneli (Kowalski, 1956), Sulimskia kretzoii (Sulimski, 1962) and Beremendia fissidens and Blarinoides mariae Sulimski, 1959. A smooth proximal part of i1 without a cingulid (present in Mafia, Sulimskia and Blarinoides) suggests its affiliation to the genus Beremendia in which the buccal cingulid is absent in most specimens. On the other hand its size is smaller than that of $B$. fissidens and points to $B$. minor. However, the very bad state of preservation of the single specimen allowed only a tentative assignment to this species.

Beremendia minor was described from the Early Villanyian (MN16) locality Rębielice Krolewskie $1 \mathrm{~A}$ in Poland and later found in two Hungarian localities, older (MN14) Osztramos 1 and younger (MN15/MN16) Osztramos 7 (Reumer, 1984).

It is also known from western Siberia and Transbaikalia (Storch et al., 1998).

Tribe BLARINELLINI Reumer, 1998

Genus PETENYIA Kormos, 1934

Petenyia dubia Bachmayer and Wilson, 1970

Figure 10.3-10.4

Material. Verkhnya Krynitsa 2 (MN11/MN12), left fragment of mandible with $\mathrm{m} 2$ and condyloid pro- cess. $\mathrm{MNI}=1$. Catalogue number 29/2/14. Lobkove $(\mathrm{MN12})$, left $\mathrm{M} 1 . \mathrm{MNI}=1$. Catalogue number 29/3/14

Description. The M1 (Figure 10.4) is quadrate in occlusal view. It is characterised by a lack of posterior emargination (hardly any posterior emargination is present). The protocone and the very small hypocone are connected forming a continuous endoloph. In occlusal view the $\mathrm{m} 2$ is relatively short and wide. Its buccal cingulid is broad and well-pronounced, the lingual cingulid is also well developed but more flat. The tooth is extremely worn so its remaining characters are not visible. The mandible is high and its lower margin is convex. The coronoid process is broken so only the lower deep part of the internal temporal fossa is present. It is closed by a horizontal bar. The interarticular area of the condyle (Figure 10.3) is low and wide. There are two mandibular foramina below the posterior corner of the internal temporal fossa.

Measurements. See Table 11.

Systematic Position and Distribution. The lack of posterior emargination and the presence of a very small hypocone which forms the endoloph with the protocone in $\mathrm{M} 1$ and the nearly quadrate $\mathrm{m} 2$ in occlusal view with large cingulids, as well as a comparatively high horizontal ramus of the mandible, internal temporal fossa with horizontal bar, and large condyloid process with a broad interarticular area show that these specimens should be placed in the tribe Blarinellini. Its morphology is very similar to the morphology of Petenyia species, especially to $P$. dubia from Podlesice. The similar in morphology and size M1 of Alloblarinella Storch, 1995 differs by a higher and straighter (without a depression between the protocone and hypocone) 
TABLE 11. Dimensions (in $\mathrm{mm}$ ) of mandible and upper and lower teeth of Petenyia dubia.

\begin{tabular}{|c|c|c|c|c|c|}
\hline & & $\begin{array}{l}\text { P. cf. dubia } \\
\text { Frunzovka } 2 \\
\text { Ukraine } \\
\text { MN11 } \\
\text { Rzebik- } \\
\text { Kowalska and } \\
\text { Nesin } 2010\end{array}$ & $\begin{array}{c}\text { P. dubia } \\
\text { Verkhnyaya } \\
\text { Krynitsa } 2 \\
\text { Ukraine } \\
\text { MN11/MN12 }\end{array}$ & $\begin{array}{c}\text { P. dubia } \\
\text { Lobkove } \\
\text { Ukraine } \\
\text { MN12 }\end{array}$ & $\begin{array}{c}\text { P. dubia } \\
\text { Podlesice } \\
\text { Zalesiaki 1B } \\
\text { Poland } \\
\text { MN14, MN14/MN15? } \\
\text { Rzebik-Kowalska 1989 and } \\
\text { new measurements }\end{array}$ \\
\hline \multirow[t]{3}{*}{ M1 } & $\mathrm{L}$ & - & - & 1.48 & - \\
\hline & $\mathrm{L}$ of med. & - & - & 1.39 & - \\
\hline & W & - & - & 1.67 & - \\
\hline \multirow[t]{2}{*}{$\mathrm{m} 2$} & L & $1.25-1.29, n=2$ & 1.30 & - & $1.18-1.29, n=23$ \\
\hline & W & $0.83-0.84, n=2$ & 0.83 & - & $0.79-0.88, n=23$ \\
\hline \multicolumn{2}{|c|}{$\mathrm{H}$ of mandible below $\mathrm{m} 2$} & 1.44 & 1.46 & - & $1.35-1.56, n=22$ \\
\hline \multicolumn{2}{|c|}{$\mathrm{H}$ of condyloid process } & - & 1.90 & - & $1.84-1.98, n=2$ \\
\hline \multicolumn{2}{|c|}{ W of interarticular area } & - & 0.74 & - & $0.71-0.77, \mathrm{n}=3$ \\
\hline
\end{tabular}

endoloph and the base of the paracone and especially the metacone placed more lingually, close to the high endoloph. The measurements agree with the measurements of $P$. dubia (see Table 10).

The age of the specimen also speaks for Petenyia dubia. It was described by Bachmayer and Wilson, in 1970 from Kohfidish in Austria, a locality dated to MN11. It is also listed from several European localities dated from the Late Miocene (MN9, Rudabánya in Hungary Kordos, 1991) to the Early Pliocene (MN14) and the Late Miocene (MN11-MN12) from Turkey (Furió et al., 2014). Petenyia cf. dubia was already mentioned from the Late Miocene (MN11) Ukrainian locality Frunzovka 2 (Rzebik-Kowalska and Nesin, 2010).

Petenyia hungarica Kormos, 1934

Material. Verkhnya Krynitsa 1 (early MN16), left fragment of i1. MNI = 1. Catalogue number 29/1/ 15.

Description. The i1 is seriously damaged in its upper and posterior sides and the narrow apex is used. The tooth pigmentation is almost black.

Measurements. Measurements are unfeasible. Systematic Position and Distribution. The i1 with strong pigmentation and a narrow apex most probably also belongs to Petenyia. On the other hand the size and age of the specimen opt for $P$. hungarica. Despite being similar in morphology and size Alloblarinella differs by the shape of the apex of i1 which is wider and more spatulate than in the i1 of Petenyia.

Petenyia hungarica lived in the Pliocene and the Pleistocene of Europe. It was also ubiquitous as the opportunistic Beremendia fissidens (RzebikKowalska, 2009).

\section{Tribe SORICINI Fischer, 1814 ZELCEINA Sulimski, 1962 Zelceina sp. \\ Figure 10.5}

Material. Verkhnya Krynitsa 2 (MN11/MN12), left M1-M2. MNI = 1. Catalogue number 29/2/16.

Description. The teeth, M1 and M2 (Figure 10.5) are of middle size, massive and quadratic in occlusal view. They are characterized by small, more or less tetrahedral hypocones, considerable metalophs and deep hypoconal flanges.

Measurements. See Table 12.

Systematic Position. The teeth described above in many respects resemble M1 and M2 of Petenyia and Zelceina. However, more detailed observation shows that they are more similar to upper molars of Zelceina because M1 and M2 of Petenyia have smaller hypocones or lack them altogether, shallower hypoconal flanges, lower metalophs and slighter posterior emargination. Moreover the size of Verkhnya Krynitsa 2 teeth also agrees with the size of known Zelceina species (see Table 12).

Two species of this genus are known so far from Europe: Zelceina soriculoides (Sulimski, 1959); and Z. podlesicensis Rzebik-Kowalska, 1990. The M1-M2 from Verkhnya Krynitsa 2 are more similar to those of $Z$. soriculoides because they are more massive than molars of $Z$. podlesicensis. Because the three converging ridges in the hypoconal region of $\mathrm{M} 1$ and $\mathrm{M} 2$ (typical for Zelceina species) are less distinct than in all known forms, and the posterior emargination is slightly more distinct, the specimen from Verkhnya Krynitsa 2 has been tentatively described as Zelceina sp.

So far Zelceina cf. podlesicensis was cited from the Ukrainian locality Mikhailovka 2 (MN11). 
TABLE 12. Dimensions (in $\mathrm{mm}$ ) of upper teeth of Zelceina species.

\begin{tabular}{|c|c|c|c|c|c|}
\hline & & $\begin{array}{c}\text { Zelceina sp. } \\
\text { Verkhnyaya Krynitsa } 2 \\
\text { Ukraine } \\
\text { MN11/MN12 }\end{array}$ & $\begin{array}{c}\text { Zelceina kormosi } \\
\text { Ertemte 2, Harr Obo } 2 \\
\text { China } \\
\text { MN13 } \\
\text { Storch } 1995\end{array}$ & $\begin{array}{c}\text { Zelceina podlesicensis } \\
\text { Podlesice } \\
\text { Poland } \\
\text { MN14 } \\
\text { Rzebik-Kowalska } 1990\end{array}$ & $\begin{array}{c}\text { Zelceina soriculoides } \\
\text { Węże } 1 \\
\text { Poland } \\
\text { MN15 } \\
\text { Rzebik-Kowalska } 1990\end{array}$ \\
\hline \multirow[t]{3}{*}{ M1 } & $\mathrm{L}$ & 1.45 & $1.48-1.64, n=10$ & $1.35-1.54, n=11$ & $1.35-1.56, n=28$ \\
\hline & L med. & 1.25 & - & $1.25-1.36, n=11$ & $1.25-1.41, n=28$ \\
\hline & W & 1.66 & $1.60-1.72, n=10$ & $1.47-1.63, n=10$ & $1.53-1.76, n=26$ \\
\hline \multirow[t]{3}{*}{ M2 } & $\mathrm{L}$ & 1.35 & 1.20-1.36, $n=10$ & $1.31-1.37, n=3$ & $1.25-1.40, n=20$ \\
\hline & $L$ med. & 1.08 & - & $1.15-1.22, n=4$ & 1.o6-1.21, $n=21$ \\
\hline & W & 1.57 & $1.48-1.72, n=10$ & $1.40-1.54, \mathrm{n}=4$ & $1.51-1.67, \mathrm{n}=21$ \\
\hline
\end{tabular}

Unfortunately, it was described on the basis of lower teeth and a comparison with the specimen discussed here is impossible (Rzebik-Kowalska and Nesin, 2010).

\section{DISCUSSION}

The remains of insectivore mammals found in eight Ukrainian localities of differing age (Late Miocene, Late Pliocene, Early and Middle Pleistocene) are fragmentary and the number of individuals and species in each of them is low except for one, the Late Miocene (MN11/MN12) Verkhnya Krynitsa 2, where 10 taxa of three families were present. The diverse assemblage of this locality contains one gymnure hedgehog, three moles and six shrews (see Table 13).

The hedgehog is represented by the fossil genus Schizogalerix. It belongs to spineless Galericinae representatives which now live exclusively in relict areas of south-eastern Asia and are indicative of a humid forest environment often close to water-bodies. The oldest remains of Schizogalerix came from the Middle Miocene of Austria (MN5) and the youngest from the late Early Pliocene (MN15) of Greece (Rzebik-Kowalska, 2009). In Ukraine it was probably widespread in the Late Miocene (MN9 to MN12) because seven localities yielded remains of this hedgehog. The spineless Galericinae disappeared almost completely from Europe at the end of the Miocene. Most probably climatic events, cooling and desiccation, around the Miocene/Pliocene boundary (in the marine record known as the Messinian salinity crisis) were responsible for the extinction of the subfamily in Europe.

Moles are represented only by Desmaninae adapted to a semiaquatic life. In the material from Verkhnya Krynitsa 2 three forms of different sizes were found. The smallest Mygalinia had a limited range (France, Hungary, Ukraine). It is known from the Late Miocene to the Early Pliocene (MN10MN11 and MN13-MN14) layers and in Ukraine it was listed in five localities dated to the late Late Miocene (MN11-MN13). The medium-sized and much more widespread Ruemkelia Rzebik-Kowalska and Pawłowski, 1994 (= Dibolia Rümke, 1985 and according to Hutterer [1995] = Archaeodesmana Topachevsky and Pashkov, 1983, see Ruemkelia sp.) was excavated throughout almost all of Europe in localities dated from the Late Miocene to the early Late Pliocene (MN9-MN16). In Ukrainian territory four Upper Miocene (MN10-MN13) localities yielded remains of this mole.

The largest and the youngest Desmana was the most abundant in Europe as well as in Ukraine. Its remains were dated from the Early Pliocene (MN14) to the Recent. However, in 2010 RzebikKowalska and Nesin described $D$. cf. nehringi Kormos, 1913 from the late Late Miocene (Late Turolian, MN13, Odessa, Sixteeth Station of Bolshoy Fontan) and in this paper the humerus of cf. Desmana sp. was described from a yet older Ukrainian locality, Verkhnya Krynitsa 2 dated to MN11/MN12. If the humerus really comes from this locality, then it is the oldest record of the genus Desmana and it moves the first appearance of this form to the Miocene (Rzebik-Kowalska, 2009). One species of this genus, $D$. moschata, still lives in Ukraine.

In Verkhnya Krynitsa 2, shrews were represented by two subfamilies: the Crocidosoricinae and the Soricinae. The first subfamily consists of small, extinct and primitive forms (with three to five, rarely two, antemolars in the lower jaw), and it is considered ancestral to all other shrews of the family Soricidae (sensu Reumer, 1987, without Heterosoricinae). The most common and most long-lived genus of this subfamily was Miosorex Kretzoi, 1959. It has been collected in many European countries (from Portugal to the Moldova Republic; Rzebik-Kowalska, 2009) and survived continuously 
TABLE 13. Number of insectivore species in the studied localities.

\begin{tabular}{|c|c|c|c|c|c|c|c|c|}
\hline & $\begin{array}{c}\text { Popovo } \\
3 \\
\text { MN11 }\end{array}$ & $\begin{array}{c}\text { Verkhnya } \\
\text { Krynitsa } 2 \\
\text { MN11/MN12 }\end{array}$ & $\begin{array}{l}\text { Lobkove } \\
\text { MN12 }\end{array}$ & $\begin{array}{c}\text { Verkhnya } \\
\text { Krynitsa } 1 \\
\text { beginning of } \\
\text { MN16 }\end{array}$ & $\begin{array}{c}\text { Popovo } 2 \\
\text { end of } \\
\text { MN16 }\end{array}$ & $\begin{array}{c}\text { Popovo } 1 \\
\text { MN16/MN17 }\end{array}$ & $\begin{array}{c}\text { Popovo } 0 \\
\text { MN17 }\end{array}$ & $\begin{array}{l}\text { Medzhybozh } \\
\text { early Middle } \\
\text { Pleistocene }\end{array}$ \\
\hline Schizogalerix sp. & + & + & - & - & - & - & - & - \\
\hline cf. Mygalinia hungarica & - & + & - & - & - & - & - & - \\
\hline Ruemkelia sp. & - & + & - & - & - & - & - & - \\
\hline Desmana sp. & - & - & - & + & + & + & - & - \\
\hline cf. Desmana sp. & - & + & - & - & - & - & - & - \\
\hline Miosorex grivensis & + & - & - & - & - & - & - & - \\
\hline cf. Miosorex sp. & - & + & - & - & - & - & - & - \\
\hline $\begin{array}{l}\text { Crusafontina cf. } \\
\text { kormosi }\end{array}$ & - & + & - & - & - & - & - & - \\
\hline cf. Asoriculus sp. & + & + & - & - & - & - & - & - \\
\hline Neomysorex alpinoides & - & + & - & - & - & - & - & - \\
\hline Neomys newtoni & - & - & - & - & - & - & - & + \\
\hline Petenyia dubia & - & + & + & - & - & - & - & - \\
\hline Petenyia hungarica & - & - & - & + & - & - & - & - \\
\hline cf. Beremendia minor & - & - & - & + & - & - & - & - \\
\hline Beremendia fissidens & - & - & - & - & + & + & + & - \\
\hline Zelceina sp. & - & + & - & - & - & - & - & - \\
\hline Number of species & 3 & 10 & 1 & 3 & 2 & 2 & 1 & 1 \\
\hline
\end{tabular}

from the early Middle Miocene (MN3) to the Late Miocene (MN11). In Ukraine it was collected in four localities dated to MN11-MN12. Cf. Miosorex sp. described from Verkhnya Krynitsa 2 (MN11/MN12) is probably the youngest and the largest Miosorex known so far. Moreover, its presence in Ukraine enlarges the geographical range of this genus eastwards. Some authors (Furió et al., 2007) thought that African mouse-shrews of the genus Myosorex Gray, 1838 could be living representatives of the subfamily Crocidosoricinae.

One shrew found in Verkhnya Krynitsa 2 represents the tribe Anourosoricini. The tribe contains highly specialised forms with more or less massive and reduced dentition. Recently its only representative, Anourosorex squamipes Milne-Edwards, 1872 (in Milne-Edwards, 1868-1874) lives in southeastern Asia. In the past, however, Anourosoricini were very diverse. They are known from Europe and North America. In Verkhnya Krynitsa 2 one form appeared - Crusafontina cf. kormosi. Very common in Europe in Ukraine was noted in three (MN10-MN11) localities.

In Verkhnya Krynitsa 2 the tribe Neomyini was represented by two shrews: the larger cf. Asoriculus sp. and the smaller Neomysorex alpinoides. Today representatives of the tribe live in Eurasia but one fossil form, Asoriculus maghrebiensis Rzebik-Kowalska, 1988 was found in Morocco (North Africa) from a locality dated to the Pliocene/Pleistocene boundary. So far, it is the first and the only find of red-toothed shrew (Soricinae) on the African continent. Throughout the Pliocene and the Early Pleistocene Asoriculus was distributed in many European countries and its oldest record came from the late Late Miocene (MN13) of Greece. In Ukraine it was found in five localities dated from MN9 to MN13. Remains from Verkhnya Krynitsa 2 and possibly also from Gritsev (MN9, its presence was only mentioned by Nesin, 2013) move its first appearance to the early Late Miocene. The second shrew, Neomysorex alpinoides, was a small species. In Ukraine it was found in two more (apart from Verkhnya Krynitsa 2) localities dated to MN11 and one more dated to the Early Pliocene (MN15). Apart from Ukraine, it is known only from Poland where it was described for the first time from the Early Pliocene Podlesice (MN14; Kowalski, 1956).

Petenyia dubia found in Verkhnya Krynitsa 2 is a representative of the tribe Blarinellini. In Ukraine it is known from three localities dated to MN11-MN12. It is uncommon but continuously present in Europe to the Early Pliocene. Its oldest remains come from Hungary (MN9). 
The genus Zelceina represents the tribe Soricini. It was described from the late Early Pliocene (MN15) locality of Węże 1 (Sulimski, 1962) in Poland. Two species, Z. podlesicensis and Z. soriculoides, are known from Pliocene localities of Europe. As remains of Zelceina are known from older sediments in China (late Late Miocene, MN13; Qiu and Storch, 2005) it was considered a newcomer from Asia. However, two Ukrainian finds of Zelceina (in Mikhailovka 2, MN11 and in Verkhnya Krynitsa 2, MN11/MN12) make the origin of Zelceina open.

The remaining seven localities yielded one to three species.

Among shrews the most interesting is Neomys newtoni found in Medzhybozh dated to the early Middle Pleistocene. This fossil Pleistocene species associated with water bodies and known from several European countries and the northern Caucasus Mt. is recorded in Ukraine for the first time.

Another interesting species is Beremendia minor (tribe Beremendiini). If its identification is correct, it is the first record of this rare shrew in Ukraine.

As it is identical in morphology with the ubiquitous European Beremendia fissidens but smaller, some authors consider that small specimens of Beremendia represent in reality females or juveniles of $B$. fissidens and called its species status into question. However, shrews have only one generation of teeth and in the case of the $B$. minor specimens, the teeth show different degrees of use and cannot represent juvenile individuals. Besides, sexual dimorphism is rather uncommon among insectivores, especially among shrews and the differences in size between the sexes of recent soricids are not striking. Moreover, in all known localities with two species there are always very few specimens belonging to $B$. minor in comparison with the numerous (sometime extremely numerous) remains of $B$. fissidens. The number of males and females of $B$. fissidens in a population is more or less similar and this should be reflected in materials originating from owl pellets.

Furthermore, Beremendia minor was found only in Pliocene faunas whereas $B$. fissidens survived until the early Middle Pleistocene. It is likely that for some reason $B$. minor is rarely found in fossils, similarly to some other soricid taxa, e.g., Paenelimnoecus or Neomys species.

The species composition in particular localities is presented in Table 13.

\section{CONCLUSIONS}

The fossil insectivore assemblages found in Ukrainian localities are similar to assemblages known in other fossil localities of Europe but still incomplete and insufficiently elaborated. Considering that in neighbouring and territorially smaller Poland the number of well documented fossil hedgehogs, moles and shrews totals 77 (in Ukraine 25, see Introduction) each new and well described assemblage enlarges and arranges the knowledge on Ukrainian and Eastern European fossil fauna of this group of mammals.

\section{ACKNOWLEDGEMENTS}

We are indebted to A. Pereswiet-Soltan for preparing illustrations as well as to the Referees for their comments.

\section{REFERENCES}

Anderson, J. 1879. Anatomical and Zoological Researches: Comprising an Account of the Zoological Results of the Two Expeditions to Western Yunnan in 1868 and 1875. Bernard Quaritch, London.

Bachmayer, F. and Wilson, R. 1970. Die Fauna der altpliozänen Höhlen- und Spalten-Füllungen bei Kohfidisch, Burgenland (Österreich). Annalen des Naturhistorischen Museums, 74:533-587.

Baudelot, S. 1972. Étude des Chiroptres, Insectivores et Rongeurs du Miocène de Sansan (Gers). Unpublished PhD Thesis, University of Toulouse, France.

Brunner, G. 1952. Die Markgrabenhöhle bei Pottenstein (Oberfranken). Neues Jahrbuch für Geologie und Paläontologie, Monatshefte, 10:457-471.

Cabrera, A. 1907. Three new Spanish insectivores. Annals and Magazine of Natural History, 7:212-215.

Crochet, J.-Y. and Green, M. 1982. Contributions á l'étude des micromammifères du gisement miocène supérieur de Montredon Hérault). 3 - Les insectivores. Palaeovertebrata, 12:119-131.

Dahlmann, T. 2001. Die Kleinsäuger der unter-pliozänen Fundstelle Wölfersheim in der Wetterau (Mammalia: Lipotyphla, Chiroptera, Rodentia). Courier Forschungsinstitut Senckenberg, 227:1-129.

De Bruijn, H., Mayda, S., van den Hoek Ostende, L.W., Kaya, T., and Saraç, G. 2006. Small mammals from the Early Miocene of Sabuncubeli (Manisa, S.W. Anatolia, Turkey). Beitráge zur Paläontologie, 30:5787.

De Jong, F. 1988. Insectivora from the Upper Aragonian and the Lower Vallesian of the Daroca-Villafeliche area in the Calatayud-Teruel Basin (Spain). Scripta Geologica, special issue, 1:253-286.

Depéret, C. 1892. La faune de mammifères miocènes de La Grive Saint-Alban (Isère) et de quelques autres localités du Bassin du Rhône. Documents nouveaus 
et revision générale. Archives du Muséum d'Histoire Naturelle de Lyon, 5:1-95.

Doukas, C.S. 1983. Insectivores (Mammalia) from the Lower Miocene of Aliveri, Evia. Unpublished PhD Thesis, Athens, Greece. (In Greek)

Doukas, C.S. 1986. The mammals from the Lower Miocene of Aliveri (Island of Evia, Greece). Proceedings. Koninklijke Nederlandse Akademie van Wetenschappen, Section B, 89:15-38.

Doukas, C.S. 2005. Greece, p. 99-112. In van den Hoek Ostende, L.V., Doukas, C.S., and Reumer, J.W.F. (eds.), The fossil record of the Eurasian Neogene insectivores (Erinaceomorpha, Soricomorpha, Mammalia), Part I. Scripta Geologica Special Issue 5.

Doukas, C.S., van den Hoek Ostende, L.W., Theocharopoulos, C.D., and Reumer, J.W.F. 1995. The vertebrate locality Maramena (Macedonia, Greece) at the Turolian-Ruscinian boundary (Neogene). Münchner Geowissenschaftliche Abhandlungen (A), 28:43-64.

Engesser, B. 1980. Insectivora und Chiroptera (Mammalia) aus dem Neogen der Türkei. Schweizerische Paläontologische Abthandlungen, 102:47-149.

Farjanel, G. and Mein, P. 1984. Une association de mammifères et de pollens dans la formation continentale des "Marnes de Bresse"'d'âge Miocène supérieur, à Ambérieu (Ain). Géologie de la France, 1-2:131-148.

Fejfar O. and Sabol, M. 2005. Czech Republic and Slovak Republic, p. 51-60. In van den Hoek Ostende, L.W., Doukas, C.S., and Reumer, J.W.F. (eds.), The fossil record of the Eurasian Neogene insectivores (Erinaceomorpha, Soricomorpha, Mammalia), Part. I. Scripta Geologica Special Issue 5.

Filhol, H. 1888. Sur un noveau genre d'insectivore. Bulletin dela Societé philomatique de Paris, serie 7, 12:24-25.

Fischer, G. 1814. In Fischer, G. 1813-1814. Zoognosia tabulis synopticis illustrata. Nicolai Sergeidis Vsevolozsky, Moscow.

Freudenthal, M. 1972. Dainogalerix koenigswaldi nov. gen., nov. spec., a giant insectivore from the Neogene of Italy. Scripta Geologica, 14:1-19.

Furió, M., Agustí, J., Mouskhelishvili, A., Sanisidro, O., and Santos-Cubedo, A. 2010. The paleobiology of the extinct venomous shrew Beremendia (Soricidae, Insectivora,Mammalia) in relation to the geology and paleoenvironment of Dmanisi (Early Pleistocene, Georgia). Journal of Vertebrate Paleontology 30:928942.

Furió, M., Casanovas-Vilar, I. and van den Hoek Ostende, L.W. 2011. Predictable structure of Miocene insectivore (Lipotyphla) faunas in Western Europe along a latitudinal gradient. Palaeogeography, Palaeoclimatology, Palaeoecology 304:219-229.

Furió M., Santos-Cubedo, A., Minwer-Barakat, R., and Agusti, J. 2007. Evolutionary history of the African soricid Myosorex (Insectivora, Mammalia) out of Africa. Journal of Vertebrate Paleontology 27:10181032.
Furió, M., van Dam, J., and Kaya, F. 2014. New insectivores (Lipotyphla, Mammalia) from the Late Miocene of the Sivas Basin, Central Anatolia. Bulletin of Geosciences 89:163-181.

Gibert, J. 1974. Etude des Insectivores du Miocène de Vallès- Penedès Calatayud-Daroca et Rubielos de Mora. Unpublished PhD Thesis, University of Barcelona, Barcelona, Spain.

Gibert, J. 1975. New Insectivores from the Miocene of Spain I and II. Proceedings Koninklijke Nederlandse Akademie van Wetenschappen, Section B, 78:108133.

Gray, J.E. 1838. Revision of the genus Sorex Linn. Proceedings of the Zoological Society of London, 1837:123-126.

Gueldenstaedt, D. 1777. Beschreibung des Desmans. Beschäftigungen der Berlinischen Gesellschaft Naturforschender Freunde, 3:107-137.

Guerin, C. and Mein, P. 1971. Les principaux gisements de mammifères Miocènes et Pliocènes du domaine rhodanien. Documents du Laboratoire de Géologie de la Faculté des Sciences de Lyon, 1:131-170.

Hinton, M.A.C. 1911. The British fossil shrews. Geological Magazine, 8:529-539.

Hutchison, J.H. 1974. Notes on type specimens of European Miocene Talpidae and a tentative classification of Old World Tertiary Talpidae (Insectivora: Mammalia). Geobios, 7:211-256.

Hutterer, R. 1995. Archaeodesmana Topachevsky and Pashkov, the correct name for Dibolia Rümke, a genus of fossil water moles (Mammalia: Talpidae). Bonner Zoologische Beitrage 45:171-172.

Jammot, D. 1977. Les musaraignes (Soricidae-Insectivora) du Plio-Pléistocène d'Europe. Unpublished PhD Thesis, University of Dijon, Dijon, France.

Kaup, J.J. 1829. Skizzierte Entwicklungsgeschichte und Natürliches System der Europäischen Thierwelt: 1203. In Commission bei Carl Wilhelm Leske, Darmstadt und Leipzig.

Kerr, R. 1792. Animal kingdom, or zoological system, of the celebrated Sir Charles Linnaeus. (Class I. Mammalia: conteining a complete systematic description, arrangement, and nomenclature, of all known species and varieties of Mammalia, or animal which suck to their young; being a translation of that part of the Systema Nature, as lately published, with great improvements, by Professsor Gmelin of Goettingen).

Kordos, T. 1991. Le Rudapithecus hungaricus de Rudabánya (Hongrie). L'Anthropologie 95:343-362.

Kormos, T. 1913. Trois nouvelles espèces fossiles des desmans en Hongrie. Annales Musei Nationales Hungarici, 11:135-146.

Kormos, T. 1930. Diagnosen neuer Säugetiere aus der oberpliozänen Fauna des Somlyóberger bei Püspökfürdö. Annales Musei Nationalis Hungarici, 27:237246.

Kormos, T. 1934. Neue Insektenfresser, Fledermäuse und Nager aus dem Oberpliozän der Villanyer Gegend. Földtani Közlöny, 64:296-321. 
Kowalski, K. 1956. Insectivores, bats and rodents from the Early Pleistocene bone breccia of Podlesice near Kroczyce (Poland). Acta Palaeontologica Polonica, 1:331-394.

Kretzoi, M. 1959. New names for soricid and arvicolid homonyms. Vertebrata Hungarica, 1:247-249.

Lartet, E. 1851. Notice sur la Colline de Sansan. Annuaire du Département du Gers 1851:1-42.

Latreille, P.A. 1829. Suite et fin des insectes. In G. Cuvier, Le règne animaldistribué d'après son organisation pour servir de base l'histoire naturelle des animaux et d'introduction l'anatomie comparée. Nouvelle edition, revue et augmente, Paris, 5.

Linnaeus, C.1758. Systema naturae pre regna tria naturae, secundum classes, ordines, genera, species, cum characteribus, differentiis, synonymis, locis. Editio decima, reformata. Laurentius Salvus, Stockholm.

Lungu, A.N. 1981. Gipparionovaya fauna Srednego Sarmata Moldavii (nasekomoyadnye, zaĭtseobraznye i gryzuny). Publihing Hause Shtiintsa, Kishinev. (In Russian)

Lungu, A. and Rzebik-Kowalska, B. 2011. Faunal Assemblages, Stratigraphy and Taphonomy of the Late Miocene Localities of Moldova. Institute of Systematics and Evolution of Animals Polish Academy of Sciences, Kraków.

Masini, F. and Fanfani, F. 2013. Apulogalerix pusillus nov. gen., nov. sp., the small-sized Galericinae (Erinaceidae, Mammalia) from the "Terre Rosse" fissure filling of the Gargano (Foggia, South-Eastern Italy). Geobios, 46:89-104.

Matschie, P. 1909. Mammalia, p. 9. In Brauer, M. (ed.), Die Süsswasserfauna Deutschlands. Eine Exkursionsfauna. Gustav Fischer Publications, Jena.

Mészáros, L.G. 1998. Crusafontina (Mammalia, Soricidae) from Late Miocene localities in Hungary. Senckenbergiana lethaea, 77:145-159.

Mészáros, L.G. 2000. Palaeogeography and environment ofthe Late Miocene Soricidae (Mammalia) fauna of the Pannonian Basin. Annales Universitatis Scientiarum Budapestinensis, Sectio Geologica, 33:107-120.

Milne-Edwards, M.A. 1868-1874. Recherches pour servir à l'histoire Naturelle des mammiferès. Masson, Paris.

Murelaga, X., Astibia, H., Sese, C., Soria, D., and Pereda-Suberbiola, X. 2004. Lower Miocene mammals from Bardenas Reales of Navarre (Ebro Basi, Iberian Peninsula). Munibe 55:7-102.

Nesin, V.A. 2013. Neogenovye Murinae (Rodentia, Muridae) Ukrainy. Monograph, Universitetskaya Kniga, Kiev. (In Russian)

Nesin, V.A. and Nadachowski, A. 2001. Late Miocene and Pliocene small mammal faunas (Insectivora, Lagomorpha, Rodentia) of Southeastern Europe. Acta Zoological Cracoviensia, 44:107-135.

Novacek, M.J. 1986. The skull of leptictid insectivorans and the higher-level classification of eutherian mam- mals. Bulletin of the American Museum of Natural History, 183:1-112.

Pashkov, A.V. and Topachevsky, V.A. 1990. Novye predstaviteli roda Desmana (Insectivora, Talpidae) iz pozdnepliotsenovykh otlozhenii tsentralnoĭ Evropy i yugo-zapada evropeřskol chasti SSSR. Vestnik Zoologii, 5:25-34. (In Russian)

Petényi, S.J. 1864. Hátrahagyott Munkái. F. Eggenberger, Budapest.

Pidoplichko, I.G. 1955. Novye dannye o faune pozvonochnykh antropogenovykh otlozhenii Ternopolskol oblasti. Doklady Akademii Nauk SSSR, 100:989-991. (In Russian)

Pidoplichko, I.G. 1956. Do vivchennya fauni antropogenovikh khrebetnikh Ternopilskoĭ oblasti. Naukovi zapiski Prirodoznavchogo Muzeyu Lvivskogo Filialu AN URSR, 5: 45-53. (In Ukrainian)

Pogorilets, O.G. (ed.) 2014. Naukovii vesnik „Medzhibizh”, 1. Mistseznakhodzhennya Medzhibizh i problemi vivchennya nizhnogo paleolitu Skhidnoevropeǐskoľ rivnini. T3OB Terno-Graf, Medzhibizh-Ternopil-Kyiv. (In Ukrainian)

Pomel, N.A. 1848. Études sur les carnassier insectivores. I. Insectivores fossils. II. Classification des insectivores. Archives des Sciences Physiques et Naturelles, 9:244-257.

Prieto, J. and Rummel, M. 2009. Erinaceidae (Mammalia, Erinaceomorpha) from the Middle Miocene fissure filling Petersbuch 68 (South Germany). Zitteliana 48/49:103-111.

Qiu, Z.D. and Storch, G. 2005. China, p. 37-50. In van den Hoek Ostende, L.W., Doukas, C. S., and Reumer, J.W.F. (eds.), The fossil record of the Eurasian Neogene insectivores (Erinaceomorpha, Soricomorpha, Mammalia), Part I, Scripta Geologica Special Issue 5.

Rabeder, G. 1973. Galerix and Lanthanotherium (Erinaceidae, Insectivora) aus dem Pannon des Wiener Beckens. Neues Jahrbuch für Geologie und Paläontologie, 7:429-446.

Rădulescu, C., Samson, P., and Ştiucă, E. 1989. Pliocene (Lower Romanian) micromammals in the Dacic Basin. Miscellanea Speologica Romanica, 1:313326.

Rekovets, L.I. 2001. Medzhybozh - mestonakhozhdenie terriofauny i mnogosloĭnaya paleoliticheskaya stoyanka cheloveka v Ukraine. Vestnik Zoologii 35:39-44.

Rekovets, L.I., Kovalchuk, O.M., and Dema, L.P. 2014. Geologiya i fauna piznogo neogenu mistseznakhodzhennya Verkhnya Krinitsa na pivdni Ukrainu, p. 111-113. In Gozyk, P. (ed.), Evolyutsiya organichnogo svitu ta etapi geologichnogo rozvitku zemli. Institut Geologichnikh Nauk, Kiev. (In Ukrainian)

Rekovets, L.I. and Pashkov, A.V. 2009. Novye mestonakhozhdeniya mikroteriofauny pozdnego neogena Ukrainy, p. 354-360. In Gozyk, P.A. (ed.), Vikopna fauna i flora Ukraini. Institut Geologichnikh Nauk NAN Ukraini, Kiev. (In Russian) 
Reumer, J.W.F. 1984. Ruscinian and Early Pleistocene Soricidae (Insectivora, Mammalia) from Tegelen (The Netherlands) and Hungary. Scripta Geologica, 73:1173.

Reumer, J.W.F. 1987. Redefinition of the Soricidae and Heterosoricidae (Insectivora, Mammalia), with the description of the Crocidosoricinae, a new subfamily of Soricidae. Revue de Paléobiologie, 6:189-192.

Reumer, J.W.F. 1998. A classification of the fossil and recent shrews, p. 5-22. In Wójcik, J. M. and Wolsan, M. (eds.), Evolution of Shrews. Mammal Research Institute Polish Academy of Sciences, Bialowieza.

Rümke, C.A. 1985. A review of fossil and recent Desmaninae (Talpidae, Insectivora). Utrecht Micropaleontplogical Bulletins. Special publication, 4, Utrecht.

Rzebik-Kowalska, B. 1976. The Neogene and Pleistocene insectivores (Mammalia) of Poland. III. Soricidae: Beremendia and Blarinoides. Acta Zoologica Cracoviensia, 22:359-385.

Rzebik-Kowalska, B. 1981. The Pliocene and Pleistocene Insectivora Mammalia) of Poland. V. Soricidae: Neomysorex n. g. and Episoriculus Ellerman et Morrison-Scott, 1951. Acta Zoologica Cracoviensia, 25:227-250.

Rzebik-Kowalska, B. 1988. Soricidae (Mammalia, Insectivora) from the Plio-Pleistocene and Middle Quaternary of Morocco and Algeria. Folia Quaternaria, 57:51-90.

Rzebik-Kowalska, B. 1989. Pliocene and Pleistocene Insectivora (Mammalia) of Poland. V. Soricidae: Petenyia Kormos, 1934 and Blarinella Thomas, 1911. Acta Zoologica Cracoviensia, 32:521-546.

Rzebik-Kowalska, B. 1990. Pliocene and Pleistocene Insectivora (Mammalia) of Poland. VI. Soricidae: Deinsdorfia Heller, 1963 and Zelceina Sulimski, 1962. Acta Zoologica Cracoviensia, 33:45-77.

Rzebik-Kowalska, B. 1991. Pliocene and Pleistocene Insectivora(Mammalia) of Poland. VIII. Soricidae: Sorex Linnaeus, 1758, Neomys Kaup, 1829, Macroneomys Fejfar, 1966, Paenelimnoecus Baudelot, 1972 and Soricidae indeterminata. Acta Zoologica Cracoviensia, 34:323-424.

Rzebik-Kowalska, B. 1994. Pliocene and Quaternary Insectivora (Mammalia) of Poland. Acta Zoologica Cracoviensia 37:77-136.

Rzebik-Kowalska, B. 1998. Fossil history of shrews in Europe, p. 23-92. In Wójcik, J. M. and Wolsan, M. (eds.), Evolution of Shrews. Mammal Research Institute Polish Academy of Sciences, Białowieża.

Rzebik-Kowalska, B. 2005. Romania, p. 135-147. In van den Hoek Ostende, L.V., Doukas, C.S., and Reumer, J.W.F. (eds.), The fossil record of the Eurasian Neogene insectivores (Erinaceomorpha, Soricomorpha, Mammalia), Part I, Scripta Geologica Special Issue 5.

Rzebik-Kowalska, B. 2009. Biodiversity of Polish Fossil Insectivores (Erinaceomorpha, Soricomorpha, Insectivora, Mammalia) Compared to the European and
Global Faunas. Institute of Systematics and Evolution of Animals Polish Academy of Sciences, Kraków.

Rzebik-Kowalska, B. 2013. Sorex bifidus n. sp. and the rich insectivore mammal fauna (Erinaceomorpha, Soricomorpha, Mammalia) from the early Pleistocene of Żabia Cave in Poland. Palaeontologia Electronica, 16, Issue 2:12A; 1-35.

Rzebik-Kowalska, B. and Lungu, A. 2009. Insectivore mammals from the Late Miocene of the Republic of Moldova. Acta Zoologica Cracoviensia, 52A:11-60.

Rzebik-Kowalska, B. and Nesin, V.A. 2010. Erinaceomorpha and Soricomorpha (Insectivora, Mammalia) from the Late Miocene of Ukraine. Institute of Systematics and Evolution of Animals Polish Academy of Sciences, Kraków.

Rzebik-Kowalska, B. and Pawłowski, J. 1994. Ruemkelia (Mammalia, Insectivora, Talpidae) nom. nov. from Dibolia Rümke, 1985 (nec Latreille, 1829). Acta Zoologica Cracoviensia, 37:75-76.

Schreuder, A. 1940. A revision of the fossil water-moles (Desmaninae). Archives Néerlandaises de Zoologie, 4:201-333.

Selänne, L. 2003. Genus Schizogalerix (Insectivora), p. 69-89. In Fortelius, M., Kappelman, J., Sen, S., and Bernor, R. (eds.), Geology and Paleontology of the Miocene Sinap Formation, Turkey. Columbia University Press, New York.

Sen, S. 1990. Stratigraphie, faunes de mammifères et magnétostratigraphie du Néogene de Sinap Tepe, Province d'Ankara, Turquie. Bulletin du Muséum National d'Histoire Naturelle 12:243-277.

Ştiucă, E., Petculescu, A., and Arghir, R. 2003. Desmana radulescui, a new Pliocene water-mole (Talpidae, Insectivora, Mammalia) from Romania, p. 71-74. In Petculescu, A. and Ştiucă, E. (eds.), Advances in Vertebrate Paleontology "Hen to Panta". Institute of Speleology "Emil Racovită”, Bucarest.

Stoetzel, E. 2013. Late Cenozoic micromammal biochronology of northwestern Africa. Palaeogeography, Palaeoclimatology, Palaeoecology 392:359-381.

Storch, G. 1995. The Neogene mammalian faunas of Ertemte and Harr Obo in Inner Mongolia (Nei Mongol), China. - 11. Soricidae (Insectivora). Senckenbergiana lathaea, 75:221-251.

Storch, G., Qiu, Z., and Zazhigin, V.S. 1998. Fossil history of shrews in Asia, p. 92-117. In Wójcik, J.M. and Wolsan, M. (eds.), Evolution of shrews. Mammal Research Institute Polish Academy of Sciences, Białowieża.

Sulimski, A. 1959. Pliocene insectivores from Węże. Acta Palaeontologica Polonica, 4:119-173.

Sulimski, A. 1962. Supplementary studies on the insectivores from Węże 1(Poland). Acta Palaeontologica Polonica, 7:441-502.

Tatarinov, K.A. 1958. Znakhidki zemleriǐki blyarini na Ukraini. Dopovidi Akademii Nauk URSR. 1:81-84. (In Ukrainian)

Thomas, O. 1912. On a collection of small mammals from the Tsin-ling Mountains, central China, pre- 
sented by Mr. G. Fenwick Owen to the National Museum. The Annals and Magazine of Natural History, London 8/10:395-403.

Topachevsky, V.O. 1956. Reshtki dribnogo verblyuda (Paracamelus alutensis) z verkhnopliotsenovikh vikladiv Pivdnya URSR. Trudi Institutu Zoologii ANU RSR, 13:93-100. (In Ukrainian)

Topachevsky, V.O. 1957a. Piznopleǐstotsenova ta golotsenova fauna ssavtsiv z suchasnikh alyuvialnikh vidkladiv nizhnogo Dnipra. Trudi Institutu Zoologii ANU RSR, 14:113-128. (In Ukrainian)

Topachevsky, V.O.1957b. Do vivchennya fauni piznopliotsenovikh ta rannoantropogenovikh khrebetnikh $\mathrm{z}$ davnikh alyuvialhikh vidkladiv pivdnya URSR. Trudi Institutu Zoologii ANU RSR, 14:141-147. (In Ukrainian)

Topachevsky, V.O. 1959. Nova forma vykhukhola z serednogo ta piznogo pleĭstotsenu URSR. Dopovidi Akademii Nauk Ukrainskor RSR, 6: 666-671. (In Ukrainian)

Topachevsky, V.A. 1961. Novyĭ pliotsenovyĭ vid vykhukholi iz Predkavkazya. Paleontologicheskii Zhurnal, 4:131-137. (In Russian)

Topachevsky, V.A. and Pashkov, A.V. 1983. Nadvidovaya sistematika vykhukholeǐ roda Desmana (Insectivora, Talpidae). Vestnik Zoologii, 3: 39-45. (In Russian)

Topachevsky, V.A. and Pashkov, A.V. 1990. Novye predstaviteli roda Desmana (Insectivora, Talpidae) iz eopleǐstotsenovykh otlozhenii yuga evroopeǐskoi chasti SSSR. Vestnik Zoologii, 1:28-38. (In Russian)

Van Dam, J.A. 2004. Anourosoricini (Mammalia: Soricidae) from the Quaternary example of recurrent climate-controlled north-south range shifting. Journal of Paleontology, 78: 741-764.

Van den Hoek Ostende, L.W. 2001. A revised generic classification of the Galericini (Insectivora, Mammalia) with some remarks on their palaeobiogeography and phylogeny. Geobios, 34:681-695.

Van den Hoek Ostende, L.W. 2003. Riddleria atecensis nov. gen. nov. sp., a peculiar erinaceid (Erinaceomorpha, Mammalia) from the Lower Miocene of Spain. Beiträge zur Paläontologie, 28:1-7.
Van den Hoek Ostende, L.W. and Doukas, C.S. 2003. Distribution and evolutionary history of the Early Miocene erinaceis Galerix symeonidisi Doukas, 1986. In Reumer, J.W.F and Wessels, W (eds.), Distribution and migration of Tertiary mammals in Eurasia. A volume in honour of Hans de Bruijn. Deinsea 10:287303.

Van den Hoek Ostende, L.W., Doukas, C.S., and Reumer, J.W.F. (eds.). 2005. The fossil record of the Eurasian Neogene insectivores (Erinaceomorpha, Soricomorpha, Mammalia), Part I. Scripta Geologica Special Issue 5.

Van den Hoek Ostende, L.W., and Furió, M. 2005. Spain, p. 148-284. In Van den Hoek Ostende, L.V., Doukas, C.S., and Reumer, J.W.F. (eds.), The fossil record of the Eurasian Neogene insectivores (Erinaceomorpha, Soricomorpha, Mammalia), Part I, Scripta Geologica Special Issue 5.

Von Meyer, H. 1865. Mitteilungen an Professor Bronn. Neues Jahrbuch für Mineralogie, Geologie und Paläontologie, Stuttgart: 215-221.

Waddell, P.J., Okada, N., and Hasegawa, M.1999. Towards resolving the interordinal relationships of placental mammals. Systematic Biology, 48:1-5.

Zaitsev, M.V. and Baryshnikov, G.F. 2002. Pleistocene Soricidae (Lipotyphla, Insectivora, Mammalia) from Treugolnaya Cave, Northern Caucasus, Russia. Acta Zoologica Cracoviensia, 45:283-305.

Ziegler, R. 2003. Shrews (Soricidae, Mammalia) from Middle Miocene karstic fissure fill sites of Petersbuch near Eichstätt, Southern Franconian Alb (Bavaria). Paläontologische Zeitschrift 77:303-322.

Ziegler, R. 2006. Insectivores (Lipotyphla) and bats (Chiroptera) from the Late Miocene of Austria. Annalen des Naturhistorischen Museums, 197A:93-196.

Ziegler, R., Dahlmann. T., Reumer, J.W.F., and Storch, G. 2005. Germany, p. 61-98. In van den Hoek Ostende, L.W., Doukas, C.S., and Reumer, J.W.F. (eds.), The fossil record of the Eurasian Neogene insectivores (Erinaceomorpha, Soricomorpha, Mammalia). Part. I. Scripta Geologica Special Issue 5.

Ziegler, R. and Fahlbusch, V. 1986. Kleinsäuger-Faunen aus der basalen Oberen Süsswasser-Molasse Niederbayerns. Zitteliana, 14:3-80. 